University of Wollongong

Research Online

Faculty of Engineering and Information

Faculty of Engineering and Information

Sciences - Papers: Part B

Sciences

2017

Ventilative cooling through automated window opening control systems to address thermal discomfort risk during the summer period: Framework, simulation and parametric analysis

Theofanis Psomas

Aalborg University

Massimo Fiorentini

University of Wollongong, massimo@uow.edu.au

Georgios Kokogiannakis

University of Wollongong, gkg@uow.edu.au

Per K. Heiselberg

Aalborg University

Follow this and additional works at: https://ro.uow.edu.au/eispapers1

Part of the Engineering Commons, and the Science and Technology Studies Commons

Research Online is the open access institutional repository for the University of Wollongong. For further information contact the UOW Library: research-pubs@uow.edu.au 


\title{
Ventilative cooling through automated window opening control systems to address thermal discomfort risk during the summer period: Framework, simulation and parametric analysis
}

\begin{abstract}
Automated window opening control systems with integrated ventilative cooling strategies may significantly diminish the thermal discomfort and overheating risk of dwellings during cooling periods in temperate climates. One of the challenges with demonstrating the benefits of the systems is the lack of building performance simulation (BPS) tools which may represent precisely how actual algorithms are applied.

The study supported herein aims to present a framework of how to simulate an advanced ventilative cooling algorithm of a window system on coupled BPS environments (ESP-r and BCVTB tools). Parametric analysis has been conducted to verify specific operational functions of the system. The analysis uses a renovated single-family house in Denmark (monitored June-August, 2016).

Parametric analysis was highlighted that the performance of the developed ventilative cooling strategy for these climatic conditions was not affected by the number of opening steps ( 3 or 5 ) for low and medium natural indoor ventilation cooling set points $\left(22-24^{\circ} \mathrm{C}\right)$. For all the examined spaces, the static trigger set points perform better than the dynamic for all the evaluating metrics and criteria that were included in this study. Under the proposed framework, the simulation of any other developed ventilative cooling concept or system is possible.
\end{abstract}

\section{Keywords}

cooling, ventilative, automated, window, opening, control, systems, address, analysis, parametric, simulation, framework, period:, summer, during, risk, discomfort, thermal

\section{Disciplines \\ Engineering | Science and Technology Studies}

\section{Publication Details}

Psomas, T., Fiorentini, M., Kokogiannakis, G. \& Heiselberg, P. (2017). Ventilative cooling through automated window opening control systems to address thermal discomfort risk during the summer period: Framework, simulation and parametric analysis. Energy and Buildings, 153 18-30. 
Ventilative cooling through automated window opening control systems to address thermal discomfort risk during the summer period: Framework, simulation and parametric analysis

\title{
Theofanis Psomas $^{\mathrm{a}}$, Massimo Fiorentini ${ }^{\mathrm{b}}$, Georgios Kokogiannakis ${ }^{\mathrm{b}}$, Per Heiselberg $^{\mathrm{a}}$
}

aFaculty of Engineering and Science, Department of Civil Engineering, University of Aalborg, 9220, Denmark

bSustainable Buildings Research Centre (SBRC), Faculty of Engineering and Information Sciences, University of Wollongong, New South Wales, 2522, Australia

Thomas Manns Vej 23, 9220, Aalborg, Denmark

tp@civil.aau.dk

Highlights

- $\quad$ ESP-r and BCVTB tools coupling is possible, with minimum computational time penalty

- $\quad$ Advanced ventilative cooling control algorithms are simulated on coupled BPS tools

- $\quad$ Developed window system control approaches are verified from numerical analysis

\begin{abstract}
Automated window opening control systems with integrated ventilative cooling strategies may significantly diminish the thermal discomfort and overheating risk of dwellings during cooling periods in temperate climates. One of the challenges with demonstrating the benefits of the systems is the lack of building performance simulation (BPS) tools which may represent precisely how actual algorithms are applied.
\end{abstract}


The study supported herein aims to present a framework of how to simulate an advanced ventilative cooling algorithm of a window system on coupled BPS environments (ESP-r and BCVTB tools). Parametric analysis has been conducted to verify specific operational functions of the system. The analysis uses a renovated single-family house in Denmark (monitored June to August, 2016).

Parametric analysis was highlighted that the performance of the developed ventilative cooling strategy for these climatic conditions was not affected by the number of opening steps ( 3 or 5 ) for low and medium natural indoor ventilation cooling set points $\left(22-24^{\circ} \mathrm{C}\right)$. For all the examined spaces, the static trigger set points perform better than the dynamic for all the evaluating metrics and criteria that were included in this study. Under the proposed framework, the simulation of any other developed ventilative cooling concept or system is possible.

$\begin{array}{ll}\text { Abbreviations } & \\ \text { BCVTB } & \text { Building controls virtual test bed software } \\ \text { BPS } & \text { Building performance simulation (tool) } \\ \text { ESRU } & \text { Energy Systems Research Unit of the University of Strathclyde } \\ \text { HVAC } & \text { Heating ventilation and air conditioning systems } \\ \text { LBNL } & \text { Lawrence Berkeley National Laboratory } \\ \text { POR } & \text { Percentage outside the range index } \\ \text { RBC } & \text { Rule based control }\end{array}$

\section{Keywords}

Residential building, simulation coupling, adaptive thermal comfort, domestic automation, building energy performance, temperate climate, renovation, ESP-r, BCVTB

\section{Introduction}

Overheating incidents indoors greatly affect health, productivity, morale, satisfaction and wellbeing of building occupants [1]. Scientific research has documented incidents of extensive overheating when mechanical cooling is not used in new nearly zero energy and in deep 
renovated residential buildings in the temperate climates of the central and western Europe [25]. A number of post-occupancy surveys have also shown elevated indoor temperatures even in heating dominated northern European temperate climates $[6,7]$. The strict requirements for high energy efficiency in building regulations, guidelines and standards for new or existing residential buildings with major renovations in temperate climates are oriented mainly to the heating season and they often underestimate the potential issues that could arise with regards to indoor air quality and thermal comfort during the warmer months (simplified monthly methods, in house not in room level; [8]). The building occupants of these climates do not have the knowledge of how to efficiently diminish their thermal discomfort indoors and their behavior, preferences and attitude might instead increase it [9].

Experimental research, in real buildings and test cells, and theoretical research have shown that attractive passive cooling methods, control strategies and technologies and more specifically ventilative cooling provide excellent indoor thermal conditions and air quality with minimum energy use [10]. The effectiveness of ventilative cooling strategies depends on the availability of a proper natural heat sink (external air mass) with satisfactory temperature gradient and the efficient thermal coupling between the sink and the thermal mass [11,12]. In most cases, night ventilation strategies could considerably decrease the peak temperature of the next day for 'free-running' buildings and the cooling load for air-conditioned spaces $[10,12]$. Extensive research has revealed that occupants in naturally ventilated residential buildings have larger comfort acceptability and suffer less from 'sick-building' symptoms compared to those in conditioned spaces $[1,13]$.

Various researchers have examined the impact on building energy consumption that the use of the natural ventilation systems (mainly windows) has in different temperate climates [14-17]. Window opening behavior is related with psychological and social factors, education, lifestyle, building characteristics, position of the opening in relation to the location of the occupants in the building and indoor and outdoor conditions [18-22]. Most of the developed models on window opening patterns refer to office buildings and moderate climates. Fabi et al. have described a methodology for the application of window opening occupant behavior for residential buildings in building performance simulation (BPS) tools [23]. Occupants control on 
window openings or simple venting schedules lead to thermal discomfort risk and unnecessary energy waste, undermining the energy savings that natural ventilation could offer [24-26].

A continuously higher penetration of automated control systems is expected in the coming years not only in large scale buildings but also in individual houses, transforming them into intelligent smart houses $[27,28]$. Building automation systems monitor, control and optimize the indoor environment, the energy use and the cost savings [29]. These systems are able to communicate with each other, return control to the user and give him feedback [29]. Karjalainen has concluded (2013) that the system characteristics which improve the level of trust between the user and the domestic system are the predictability, the transparency, the individual control opportunities, the simplicity, the usability and the suitability for daily life [30]. Automated window control opening systems, with integrated smart algorithms, hereafter called 'window systems', that match the needs of occupants and the building characteristics have high saving potential for ventilation and cooling $[26,31,32]$.

Window systems with rule-based-control (RBC; heuristic control) are the conventional approach and the industry standard [33]. The RBC is based on 'IF (condition)-THEN (action)' rules and introduce the expert knowledge into the control loop [34]. Advanced window systems are complex (especially for large buildings), need sufficient computing power (huge data collection), are model and assumptions dependent (fidelity), are expensive for medium size buildings, and are not user friendly for operators [35,36]. Schulze et al. (2013) and Martin et al. (1996) concluded that complex algorithms in many buildings do not perform better than simple ones and setting parameters proved more important than the control strategy itself $[37,38]$. Literature review concludes that there were no well documented, mature and validated BPS tools which could represent the state-of-the-art ventilation and passive cooling control strategies $[11,37]$. Controls improve performance considerably and, as a result, the control representation in BPS tools needs to mirror precisely how actual algorithms are developed and applied [39]. Idealized controls that exist in many tools cannot substitute these algorithms effectively [39]. The study supported herein aims to present a methodology and a framework of how to simulate a developed ventilative cooling algorithm of a window system on time-step coupled BPS environments. The window system is oriented to address mainly overheating risk during peak summer periods. The ventilative cooling algorithm is presented analytically in 
Section 2.1. In addition, parametric analysis has been conducted to document and verify specific operational functions of the window system. These operational functions are related mainly with the number of steps of window opening (step-approach) and the nature (dynamic or static) of the indoor natural ventilation cooling set point (Section 2.1). The window system at its current form uses a 5-steps approach and static indoor natural ventilation cooling set points. This analysis used a 1930s single-family deep renovated house close to Copenhagen, Denmark and the BPS software ESP-r. For the simulation and realistic representation of the control algorithm, the ESP-r software is coupled with Building Controls Virtual Test Bed (BCVTB) tool. The model was calibrated to represent, as close as possible, the real indoor environment (operative temperature) of the dwelling $\left(13^{\text {th }}-18^{\text {th }}\right.$ June 2016$)$. The calibration process is highlighted as the initial part of the proposed framework and workflow for the verification and documentation of the ventilative cooling performance of the developed window systems or any other window system. In addition, the conclusions of the parametrical analysis (June to August 2016), as far as the examined operational functions of the window system, will be directly applicable for the further development of the system. Both static and dynamic thermal discomfort and overheating risk metrics and criteria are used to perform comfort assessment for the whole period of the analysis.

\section{Methodology}

\subsection{Software description and coupling}

For the realistic representation and simulation of the function of the new developed window system (effect to the dynamic thermal environment), a custom virtual environment has been created with the use of two well-documented tools, ESP-r and BCVTB (Fig. 1). A limited number of building simulation software has currently the capability to simulate the effects of a relatively complex algorithm for natural ventilation and ventilative cooling, and for this reason a time step coupling with an external emulator for controllers has been considered. ESP-r and BCVTB could offer the possibility to achieve this goal, if their standard capabilities are extended to include external controller of flow network components $[40,41]$. The connection between ESP$r$ and BCVTB was previously developed and presented by Hoes et al. [42]. In this research work the HVAC heating and cooling load was managed by a controller, developed in Matlab, 
via BCVTB. In a previous study, focused on an evaluation methodology and implementation for natural ventilation control strategies, Fiorentini et al. (2016) integrated the BCVTB communication functions in the ESP-r code to achieve time step control of the opening components [43].

ESP-r is a state-of-the-art open-source BPS software initially developed by the Energy Systems Research Unit at the University of Strathclyde (ESRU; [40,44]). ESP-r is based on the finite volume method and it has been under constant development and validation for more than three decades $[45,46]$. Dynamic thermal building response and multi-zone airflow phenomena are accurately represented in ESP-r [47]. A further advantage is that the ESP-r code is transparent to developers and may easily be expanded, modified and recompiled [40,44]. The integrated airflow network allows air paths to be described in detail (response to outdoor conditions and control; [46]). Generic pressure and flow resistances coefficient are integrated in the tool and are described in [47]. Typical window controllers use indoor air temperature (virtual sensor) to trigger opening (actuator) at a certain percentage and/or proportional control with hysteresis above a benchmark [48]. The open nature of the code allows the development and integration of self-developed algorithms and link with other tools $[42,43,49]$.

BCVTB (version 1.5.0) is an open-source (Java based) and free available software platform developed by Lawrence Berkeley National Laboratory (LBNL) for coupling different simulation programs (middleware) and information exchange (real-time data exchanger; [41]). BCVTB is an extension of Ptolemy II, a program developed for heterogeneous simulations [50]. Relatively complex controls and algorithms may also be implemented directly in its interface.

The coupling of the two tools was achieved by modifying the relevant sections of the ESP-r code of the branch called 'ESP-r_BCVTB', and re-compiling it. The code alterations were made in the files 'mfs.F', which manages the flow network calculations, and 'mfcntl.F', which contains the code of the controllers. The combination of the two tools for the flow network components is not direct and requires a certain level of programming of building simulation software knowledge. The computational time in this case remained almost unaltered when compared to a simulation of a standard ESP-r model without external coupling.

The input data may be categorized into two types: parameters and variables. The parameters refer to the data that remains constant during the building simulation process and variables 
refer to the data that might change during the simulation. The coupling of the two software allows the exchange of an array of numerical values between the ESP-r model and the BCVTB controller at the beginning of each time step (measured states, $x(k)$, and measured disturbances $u_{d}(k)$ at each time step k; Fig. 1). The measured states array includes the zones indoor operative temperatures. The measured disturbance is the outdoor temperature (current time is also exchanged). The arrays of measured and disturbances states replicate the realtime sensor measurements that act as inputs in the window system. The control loop closes with the BCVTB controller, which could emulate any control logic and return an array of opening percentages $u_{c}(k)$ for all the operable windows in each zone.

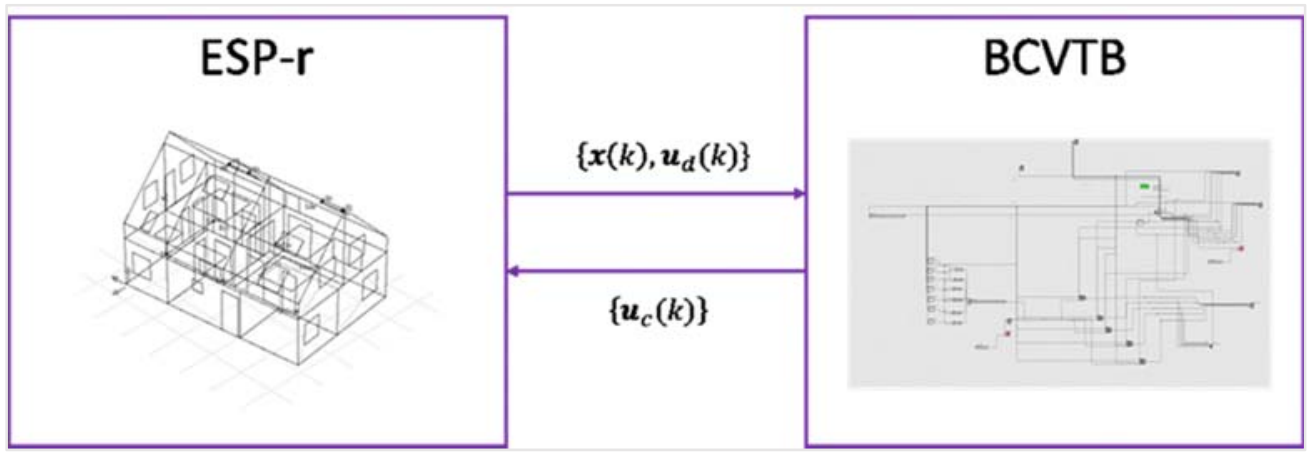

Fig. 1 Graphical representation of the communication architecture (measured state-disturbance and window opening) of the coupled tools (ESP-r and BCVTB).

The ventilative cooling algorithm of the window system is summarized below (Fig. 2). The operable windows in each zone are activated by independent controllers. Windows of every examined zone open incrementally with 5 discreet steps when the ambient air temperature is lower than the indoor operative zone temperature and when the indoor operative temperature is higher than the indoor natural ventilation cooling set point. Indoor ventilative cooling set point is a static operative temperature set point at its current form. The 5 discrete steps for window opening were $10 \% / 25 \% / 50 \% / 75 \% / 100 \%$ of the motor actuator, as described in detail in [26]. After each control time step, which in this study was considered to be equal to 30 minutes, if the indoor operative temperature is higher than the previous time step, the opening percentage increases to the next incremental step, otherwise the opening remains unchanged. The 
algorithm was applied to all the roof windows of the zones of the upper floor of the case study presented in Section 2.2.

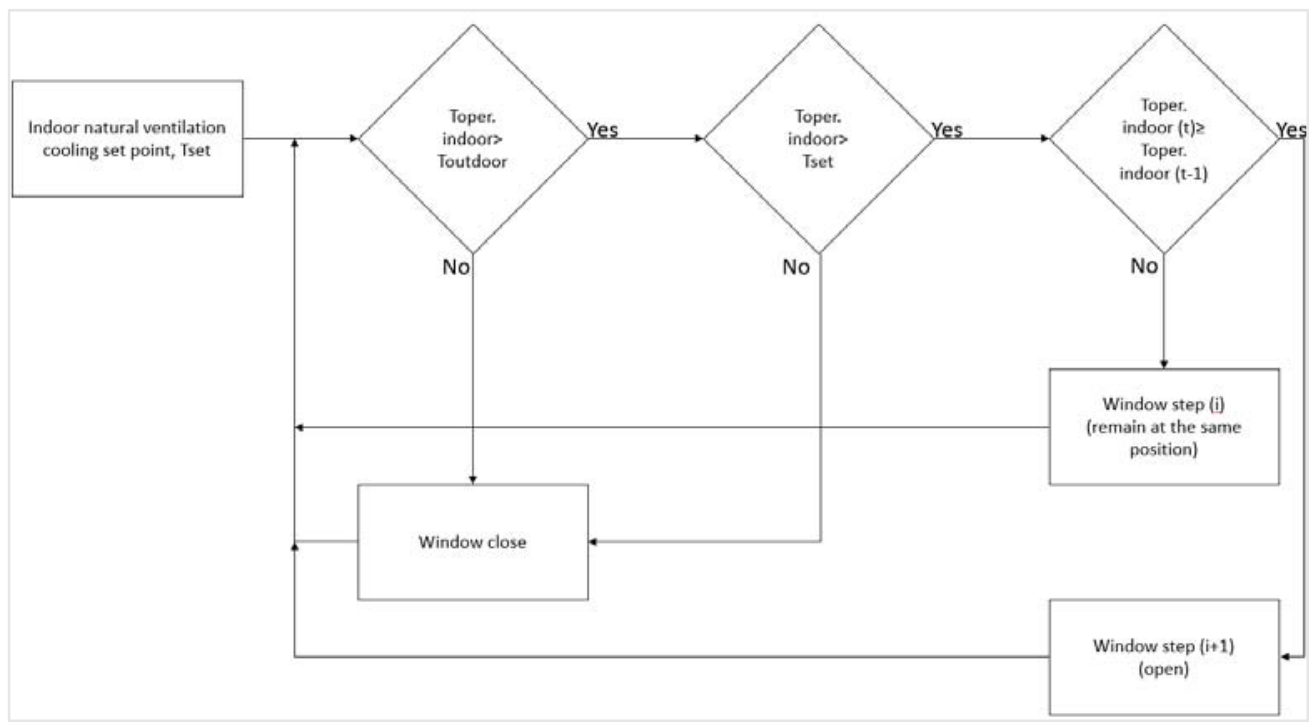

Fig. 2 Ventilative cooling algorithm integrated to window system. (T: stands for operative temperature (zone), $\mathrm{T}_{\text {set: }}$ stands for indoor natural ventilation cooling set point (dynamic or static), i: stands for window opening step (maximum 3 or 5-steps) and t: stands for time interval (30 minutes)).

\subsection{Case Study}

This section presents the technical and thermal characteristics and details of the dwelling used to demonstrate the method for enabling the windows opening algorithm to be modelled when the ESP-r building simulation tool is coupled with the BCVTB controls emulator platform. The algorithm was implemented in a real house, which was audited and monitored to collect data for calibrating the building model. The simulated house is a typical 1930s yellow-brick singlefamily house located at a suburban area close to Copenhagen, Denmark. The gross area and the surface-to-net-volume ratio are $172.4 \mathrm{~m}^{2}$ and $0.47 \mathrm{~m}^{-1}$ respectively. The house is a twostorey detached building with a pitched roof and a basement. It is surrounded by vegetation at the southern orientation. The house is occupied by a four-member working family with two children and has been significantly renovated over the last years. The deep renovation covers the increase of the efficiency of the building envelope and the installation of nine highperformance pivot roof windows with electrically driven motors and actuators. Both floors have 
external brick walls. For the ground floor, the insulation is inside the external wall (compressed), and for the upper floor, the insulation is internal (with gypsum boards covering). The roof windows with the integrated shading systems were installed at the corridor, the W.C. and the three bedrooms (Fig. 3). Side-hung windows are double-glazed from the middle 1990s (not renovated). The doors of the house are wooden and the internal space is light-white colored. The service rooms are at the ground floor and through stairs there is a connection with the basement. The balcony on the south part of the upper floor functions as an overhang for the facade windows of the ground floor. Table 1 presents the thermal characteristics (U-value) of the case study envelope elements (both floors). Table 2 presents the window-to-net floor area ratio for all the examined rooms of the upper floor of the house.

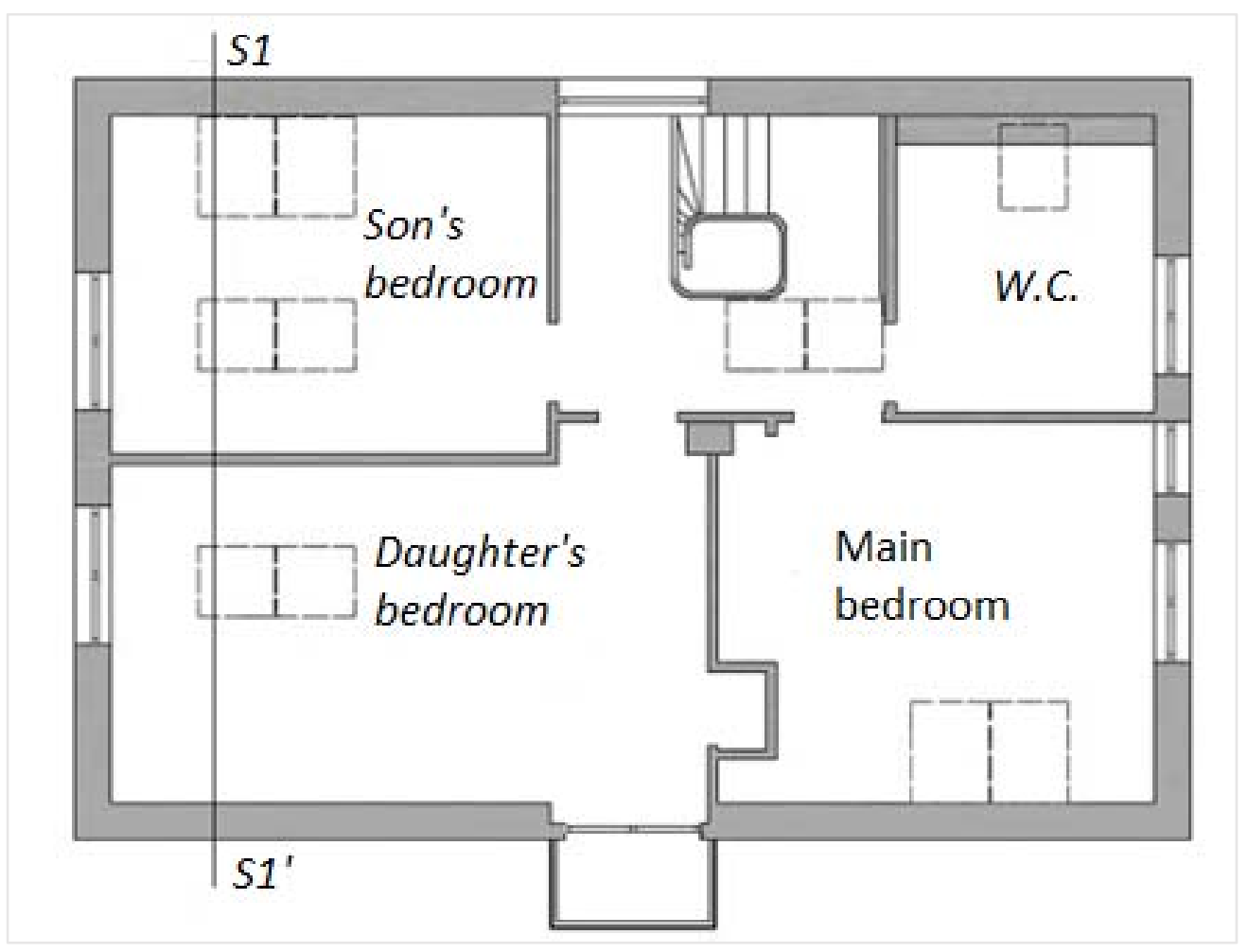

Fig. 3. Architecture floor plan of the simulated upper floor (three bedrooms, W.C. stairs and corridor) of the examined case study (roof and façade windows are indicated).

The case study has been simulated according to its design specifications in ESP-r (Table 1), with an airflow network that accounts for internal air movement between spaces, ventilation through windows and infiltration. The internal thermal mass values and the thermal 
characteristics of the non-renovated materials (e.g. old Danish bricks) were extracted from International Standards [51]. The case study has been simulated as a 'free-running' building without mechanical ventilation and active systems (heating and cooling) for the three examined summer months (June, July and August) of 2016 (Fig. 4). The only simulated active system was the controllable window system. The façade windows of both floors (used only the roof windows) remained closed for the total examined period and the active shading system was not used during the simulation. Tables 3 and 4 present information about the occupancy and the internal heat gain profiles (appliances and lighting) respectively for two day types (weekday, weekends). The occupancy profile was derived from an interview-survey with the family. Default values for the radiant and convective fraction of the internal gains has been used [46]. Homogeneous air properties and full air-mixing were assumed as well [47]. The initialization (warm-up) period for the analyses of this research work was 15 days.

\section{Table 1}

$\mathrm{U}$-value $\left(\mathrm{W} / \mathrm{m}^{2} \mathrm{~K}\right)$ of the simulated envelope elements of the case study (both floors).

\begin{tabular}{ccccccc}
\hline Floor & $\begin{array}{c}\text { External } \\
\text { wall }\end{array}$ & $\begin{array}{c}\text { Ceiling- } \\
\text { roof }\end{array}$ & $\begin{array}{c}\text { Internal } \\
\text { partition }\end{array}$ & Floor & $\begin{array}{c}\text { Façade } \\
\text { windows }\end{array}$ & Roof \\
& 0.37 & 0.21 & 2.48 & 0.19 & 2.70 & - \\
\hline Ground & 0.16 & 0.11 & 0.32 & 0.21 & 2.70 & 1.10 \\
\hline
\end{tabular}

Table 2

Window-to-net floor area ratio (\%) for the different examined rooms of the upper floor.

\begin{tabular}{ccccc}
\hline & & Main & Daughter's & \\
Corridor & W.C. (North- & room & Son's room \\
(North) & East) & bedroom & (South- & (North-West) \\
& & (South-East) & West) & \\
& 28 & 30 & 32 & 36 \\
\hline 31 & & & & \\
\hline
\end{tabular}


Table 3

Developed occupancy daily profile (weekdays and weekend; office, dining room and living room: 108 Watts, kitchen: 126 Watts and bedroom: 90 Watts).

\begin{tabular}{|c|c|c|c|c|c|c|}
\hline \multirow{2}{*}{$\begin{array}{l}\text { Hour of } \\
\text { the day }\end{array}$} & \multicolumn{3}{|c|}{ Weekdays } & \multicolumn{3}{|c|}{ Weekend } \\
\hline & Parent 1 & Parent 2 & Children & Parent 1 & Parent 2 & Children \\
\hline 1 & Bedroom & Bedroom & Bedroom & Bedroom & Bedroom & Bedroom \\
\hline 2 & Bedroom & Bedroom & Bedroom & Bedroom & Bedroom & Bedroom \\
\hline 3 & Bedroom & Bedroom & Bedroom & Bedroom & Bedroom & Bedroom \\
\hline 4 & Bedroom & Bedroom & Bedroom & Bedroom & Bedroom & Bedroom \\
\hline 5 & Bedroom & Bedroom & Bedroom & Bedroom & Bedroom & Bedroom \\
\hline 6 & Bedroom & Bedroom & Bedroom & Bedroom & Bedroom & Bedroom \\
\hline 7 & Bedroom & Bedroom & Bedroom & Bedroom & Bedroom & Bedroom \\
\hline & Dining & Dining & Dining & Dining & Dining & Dining \\
\hline & room & room & room & room & room & room \\
\hline 9 & - & - & - & $\begin{array}{l}\text { Office } \\
\text { room }\end{array}$ & $\begin{array}{l}\text { Living } \\
\text { room }\end{array}$ & Bedroom \\
\hline 10 & - & - & - & $\begin{array}{l}\text { Office } \\
\text { room }\end{array}$ & $\begin{array}{l}\text { Living } \\
\text { room }\end{array}$ & Bedroom \\
\hline 11 & - & - & - & $\begin{array}{l}\text { Office } \\
\text { room }\end{array}$ & $\begin{array}{l}\text { Living } \\
\text { room }\end{array}$ & Bedroom \\
\hline 12 & - & - & - & $\begin{array}{l}\text { Office } \\
\text { room }\end{array}$ & $\begin{array}{c}\text { Living } \\
\text { room }\end{array}$ & Bedroom \\
\hline 13 & - & - & - & $\begin{array}{l}\text { Office } \\
\text { room }\end{array}$ & $\begin{array}{c}\text { Living } \\
\text { room }\end{array}$ & Bedroom \\
\hline 14 & - & - & - & $\begin{array}{l}\text { Office } \\
\text { room }\end{array}$ & $\begin{array}{c}\text { Living } \\
\text { room }\end{array}$ & Bedroom \\
\hline 15 & - & - & - & $\begin{array}{l}\text { Office } \\
\text { room }\end{array}$ & $\begin{array}{c}\text { Living } \\
\text { room }\end{array}$ & Bedroom \\
\hline
\end{tabular}




\begin{tabular}{|c|c|c|c|c|c|c|}
\hline 16 & - & - & - & $\begin{array}{l}\text { Office } \\
\text { room }\end{array}$ & $\begin{array}{l}\text { Living } \\
\text { room }\end{array}$ & Bedroom \\
\hline 17 & $\begin{array}{l}\text { Living } \\
\text { room }\end{array}$ & Kitchen & $\begin{array}{l}\text { Living } \\
\text { room }\end{array}$ & $\begin{array}{l}\text { Living } \\
\text { room }\end{array}$ & Kitchen & Bedroom \\
\hline 18 & $\begin{array}{l}\text { Dining } \\
\text { room }\end{array}$ & $\begin{array}{l}\text { Dining } \\
\text { room }\end{array}$ & $\begin{array}{l}\text { Dining } \\
\text { room }\end{array}$ & $\begin{array}{l}\text { Dining } \\
\text { room }\end{array}$ & $\begin{array}{l}\text { Dining } \\
\text { room }\end{array}$ & $\begin{array}{l}\text { Dining } \\
\text { room }\end{array}$ \\
\hline 19 & $\begin{array}{l}\text { Living } \\
\text { room }\end{array}$ & $\begin{array}{l}\text { Living } \\
\text { room }\end{array}$ & Bedroom & $\begin{array}{l}\text { Living } \\
\text { room }\end{array}$ & $\begin{array}{l}\text { Living } \\
\text { room }\end{array}$ & Bedroom \\
\hline 20 & $\begin{array}{l}\text { Office } \\
\text { room }\end{array}$ & $\begin{array}{l}\text { Living } \\
\text { room }\end{array}$ & Bedroom & $\begin{array}{l}\text { Living } \\
\text { room }\end{array}$ & $\begin{array}{l}\text { Living } \\
\text { room }\end{array}$ & Bedroom \\
\hline 21 & $\begin{array}{l}\text { Office } \\
\text { room }\end{array}$ & $\begin{array}{l}\text { Living } \\
\text { room }\end{array}$ & Bedroom & $\begin{array}{l}\text { Living } \\
\text { room }\end{array}$ & $\begin{array}{l}\text { Living } \\
\text { room }\end{array}$ & Bedroom \\
\hline 22 & $\begin{array}{l}\text { Office } \\
\text { room }\end{array}$ & $\begin{array}{l}\text { Living } \\
\text { room }\end{array}$ & Bedroom & $\begin{array}{l}\text { Living } \\
\text { room }\end{array}$ & $\begin{array}{l}\text { Living } \\
\text { room }\end{array}$ & Bedroom \\
\hline 23 & $\begin{array}{l}\text { Office } \\
\text { room }\end{array}$ & $\begin{array}{l}\text { Living } \\
\text { room }\end{array}$ & Bedroom & $\begin{array}{l}\text { Living } \\
\text { room }\end{array}$ & $\begin{array}{l}\text { Living } \\
\text { room }\end{array}$ & Bedroom \\
\hline 24 & Bedroom & Bedroom & Bedroom & Bedroom & Bedroom & Bedroom \\
\hline
\end{tabular}

Table 4

Internal heat gains daily profile [52].

\begin{tabular}{ccc}
\hline Hour of the day & Appliances $\left(\mathrm{x} 2.4 \mathrm{~W} / \mathrm{m}^{2}\right)$ & Lighting $\left(\times 8.0 \mathrm{~W} / \mathrm{m}^{2}\right)$ \\
\hline 1 & 0.5 & 0.0 \\
2 & 0.5 & 0.0 \\
3 & 0.5 & 0.0 \\
4 & 0.5 & 0.0 \\
5 & 0.5 & 0.0 \\
6 & 0.5 & 0.0 \\
7 & 0.5 & 0.15 \\
8 & 0.7 & 0.15 \\
9 & 0.7 & 0.15 \\
\hline
\end{tabular}




\begin{tabular}{lll}
\hline 10 & 0.5 & 0.15 \\
11 & 0.5 & 0.05 \\
12 & 0.6 & 0.05 \\
13 & 0.6 & 0.05 \\
14 & 0.6 & 0.05 \\
15 & 0.6 & 0.05 \\
16 & 0.5 & 0.05 \\
17 & 0.5 & 0.2 \\
18 & 0.7 & 0.2 \\
19 & 0.7 & 0.2 \\
20 & 0.8 & 0.2 \\
21 & 0.8 & 0.2 \\
22 & 0.8 & 0.2 \\
23 & 0.6 & 0.15 \\
24 & 0.6 & 0.15 \\
\hline
\end{tabular}

Real weather data of global radiation, wind speed intensity and direction (June to August, 2016) were taken from the closest meteorological station of the Danish Meteorological Institute, Sjælsmark, $3.7 \mathrm{~km}$ away from the building (Figs. 4 (a-c)). The outdoor ambient temperature was measured in-situ, with a calibrated sensor (Netatmo sensor) that was totally protected from solar radiation by being encapsulated in silver plastic box (Table 6). Weather conditions during the examined summer period (June to August, 2016) were typical for the area and period [26]. The hottest month, in terms of average temperatures, was July followed by June. August had the highest and the lowest temperature during the 3-month examined period. The wind intensity ranged mainly from 1.4 to $3.9 \mathrm{~m} / \mathrm{s}$ (North-West and South-West orientations). 


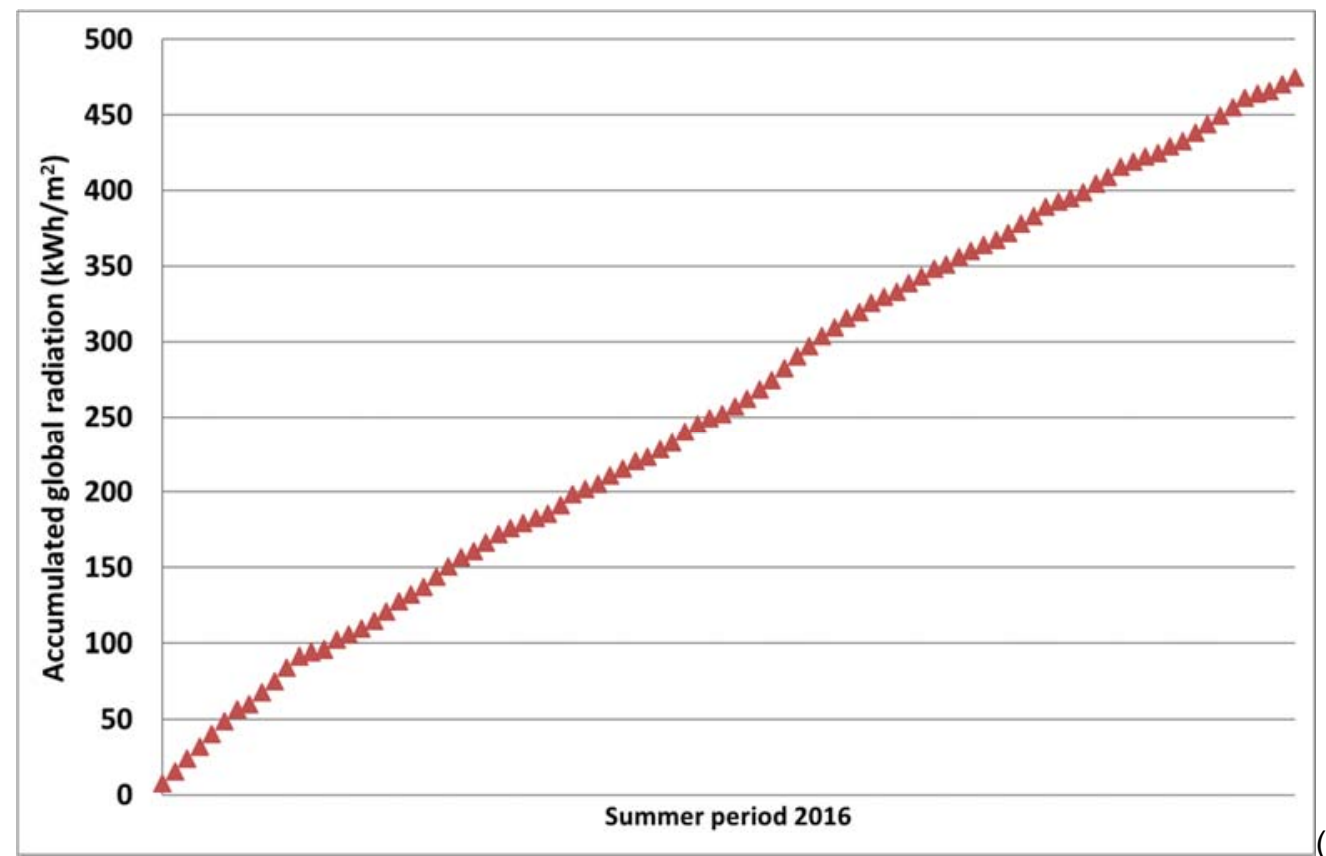

(a)

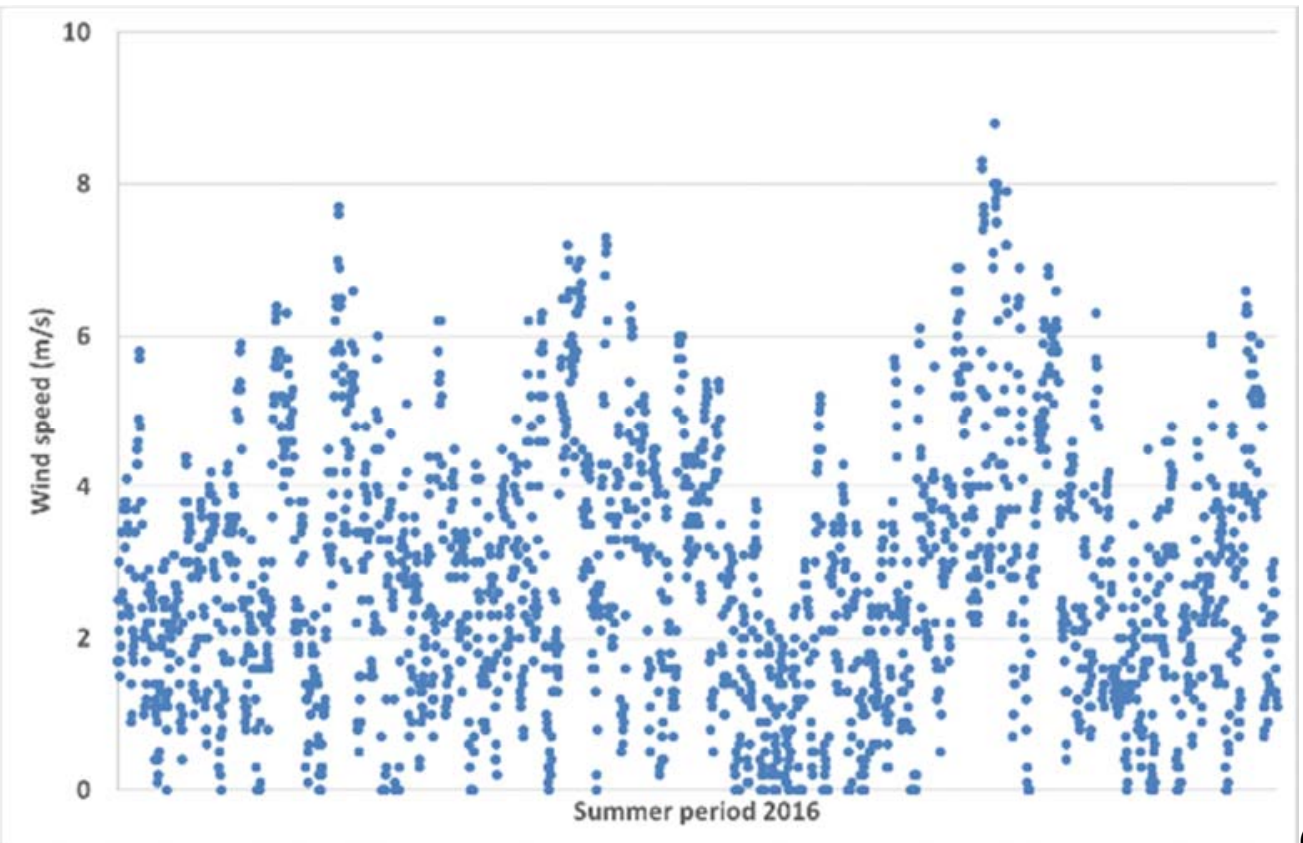

(b) 

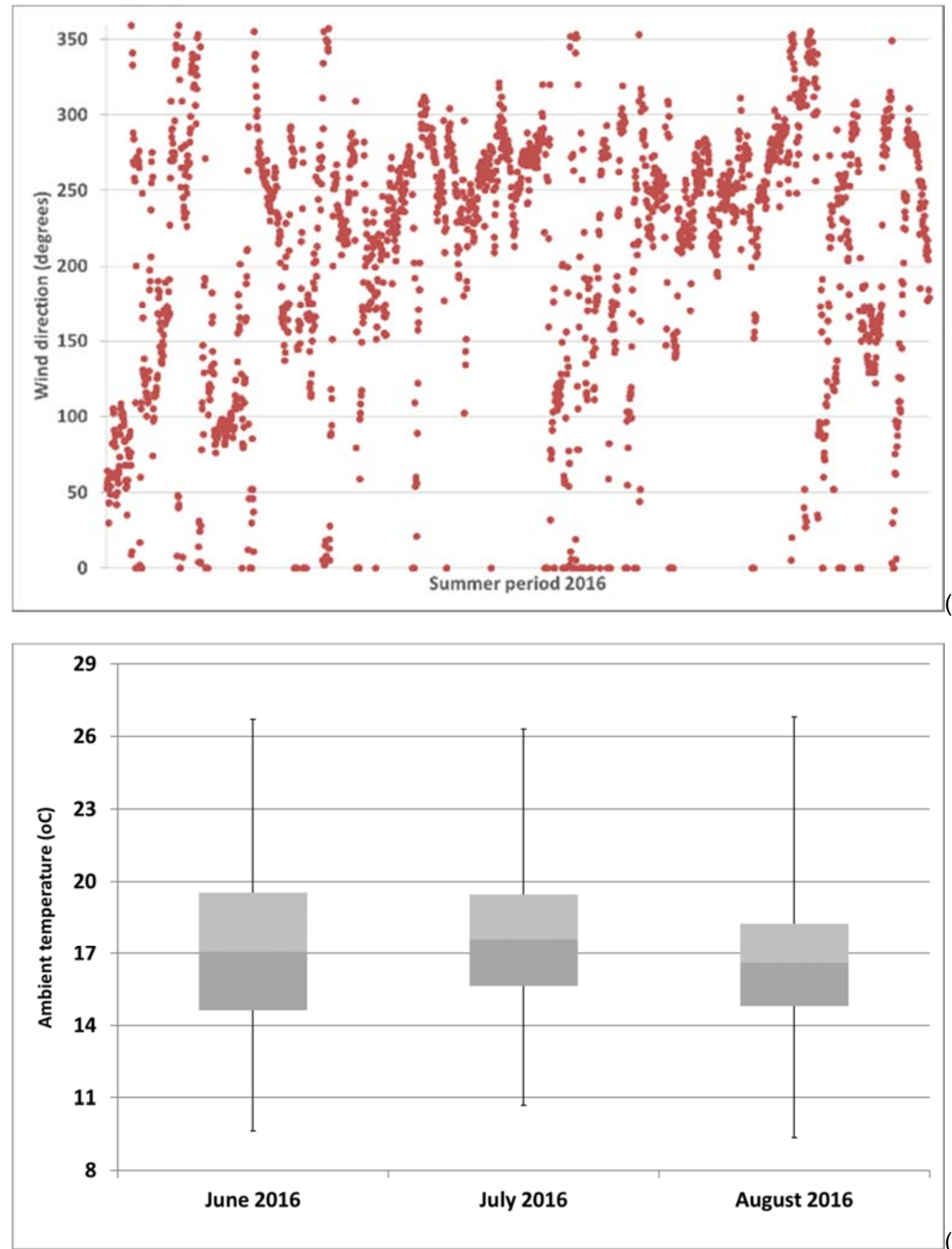

(d)

Fig. 4. a) Accumulated horizontal global solar radiation $\left(\mathrm{kWh} / \mathrm{m}^{2}\right)$, b) wind speed $(\mathrm{m} / \mathrm{s})$, c) wind direction (degrees) and d) ambient air temperature $\left({ }^{\circ} \mathrm{C}\right)$ of the location of the dwelling during the summer period (June to August) of 2016.

\subsection{Performance indicators}

For more than seven decades, over 160 different climatic stress indices have been developed and have been reported in the literature [53], of which over seventy indices (70) were for 
overheating risk assessments [54]. The majority of these indices are related either on comfort models and acceptability ranges or health evidences [55]. For the past years, a new discomfort index has been developed describing in one number the long-term discomfort of indoor spaces for different building types [52,54]. The index was embedded in the derived dynamic adaptive models and tools, which are used widely for naturally ventilated and non-mechanically cooled residential buildings, because it was found that they reflect the user's perceptions and experiences for thermal comfort in these types of buildings [52]. In houses, there are different ways of thermal adaptation through clothing and activity modification and environmental control on building systems (windows, blinds, fans and others; [56,57]).

This research work uses two widely applied metrics and four criteria for the assessment of the discomfort conditions during the examined period. The first metric is the "percentage outside the range-POR", which accumulates the hours over the examined-simulated period (percentage of total hours) during which the indoor zone operative temperature is higher or lower than the boundaries-limits of the dynamic adaptive comfort theory (Eqs. (1) and (2); [52]). Table 5 presents the Categories for the values to be used when calculating the upper and lower limits of Eq. 1. Category I refers to buildings occupied by fragile or elderly people, with high level of expectations in terms of indoor conditions and thermal comfort [52]. Category II represents a normal level of expectation (new buildings or renovations). Category III represents an acceptable-moderate level (existing buildings). Category IV is acceptable only during a limited part of the year. The first part (without category range) of Eq. 1 is the comfort temperature.

$T_{i, o p \cdot \max / \min }=0.33^{\star} T_{r m}+18.8 \pm$ Category range limit (Equation 1$)$

$T_{r m}=\left(T_{\text {ed-1 }}+0,8^{\star} T_{\text {ed-2 }}+0,6^{\star} T_{\text {ed-3 }}+0,5^{\star} T_{\text {ed-4 }}+0,4^{\star} T_{\text {ed-5 }}+0,3^{\star} T_{\text {ed- }-6}+0,2^{\star} T_{\text {ed- }-7}\right) / 3.8$ (Equation 2)

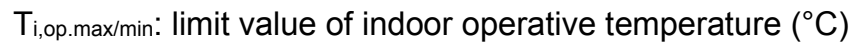

$\mathrm{T}_{\mathrm{rm}}$ : running mean outdoor temperature $\left({ }^{\circ} \mathrm{C}\right)$.

$T_{\text {ed-i: }}$ daily mean ambient temperature for the previous i day $\left({ }^{\circ} \mathrm{C}\right)$ 
Table 5

Limit value of indoor operative temperature for the different Categories [52].

\begin{tabular}{cccc}
\hline & Category I & Category II & Category $\mathrm{II}^{*}$ \\
\hline Upper limit & +2 & +3 & +4 \\
Lower limit & -3 & -4 & -5 \\
\hline & & & \\
\hline Category IV includes the indoor operative temperatures above or below the other Categories.
\end{tabular}

The second metric is the temperature excess which is defined as the cumulative number of hours with indoor operative temperatures over static thresholds. Literature extensively uses this method because it is simple and easily understandable and communicable by non-technical users [54]. Danish regulations forward fixed thresholds and hours of exceedance for critical rooms (100 hours over $27^{\circ} \mathrm{C}$ and 25 hours over $28^{\circ} \mathrm{C}$; [8]). This research work employs the suggested static thresholds of the Danish regulations for the assessment of the overheating risk (percentage of time, \%). The compliance with the regulations for both metrics and criteria is outside of the interest of this research work [8,52].

\section{Results and discussion}

\subsection{Model calibration}

The first step prior to simulating the performance of the ventilative cooling method with the different control options was to undertake a model calibration process. The calibration process is highlighted as the initial part of the proposed framework for the verification of the ventilative cooling performance of the developed window systems or any other window system. In addition, the conclusions of the parametrical analysis, as far as the examined operational functions of the window system, will be directly applicable for the further improvement of the system.

The model was calibrated using house monitoring data acquired between $13^{\text {th }}-18^{\text {th }}$ June. The indoor sensors (similar with the outdoor sensors; [58]) were calibrated and installed in locations, where they were not exposed to direct solar radiation and heat sources (Table 6). Only the rooms of the upper floor ( 3 bedrooms, corridor and W.C.) were monitored during this period. During the calibration period the dwelling was not occupied. Internal gains from the equipment 
were minimal and the façade-roof window and shading elements of the upper floor were under the control of the research team (closed and open respectively).

The following three criteria were taken from these studies in the literature $[59,60]$ and were used in this work for the aforementioned case study model, to verify the agreement between the two datasets (simulated and measured) for each individual zone of the upper floor of the house:

a) Visual observation of general trends and time shifts (misalignment) between measurements and predictions.

b) Magnitude-fit metric defined as the absolute average temperature difference between the datasets. In the analysis, results less than $1.00^{\circ} \mathrm{C}(<1.00)$ were classed as "acceptable", although the actual acceptable ranges for calibration purposes would depend on the context of the comparison [60].

c) Shape-fit metric defined through the calculation of the Spearman's rank correlation coefficient and it highlights the level of correspondence (shape profile). In the analysis, results over 0.80 $(>0.80)$ were classed as "acceptable" [60].

Although care was taken to ensure that model parameters were as accurate as possible to the real thermo-physical counterparts, there will still be uncertainty due to reasons related for example with uncertainty in thermo-physical properties of the envelope materials (poor craftsmanship and thermal bridges), glazing properties, infiltration and door openings, sensors accuracy and temperature stratification, erroneous selection of pressure coefficients and other reasons. Ad hoc calibration of the developed model was conducted to gauge the effect of assumptions on modelling parameters on the experimental response.

Figs. 5 (a-c) present the monitored and simulated data series for three representative rooms of the upper floor. The comparison by visual observation shows adequate agreement, with maximum and minimum values occurring in a similar way and with the overall temperature fluctuations to follow a similar pattern. In addition, Table 7 presents the shape-fit and the magnitude-fit metrics for all the calibrated rooms. All rooms fulfill the requirements of the aforementioned metrics. 
Table 6

Range and accuracy levels of the sensors of the environmental parameters [61].

\begin{tabular}{lccc}
\hline Metrics & $\begin{array}{c}\text { Temperature } \\
\left({ }^{\circ} \mathrm{C}\right)\end{array}$ & $\begin{array}{c}\text { Relative } \\
\text { humidity }(\%)\end{array}$ & $\begin{array}{c}\text { Carbon } \\
\text { dioxide } \\
\text { concentration } \\
(\mathrm{ppm})\end{array}$ \\
& & & \\
& $0 \div 50$ & & $0 \div 5000$ \\
Range & $($ indoor $) /$ & $0 \div 100$ & \\
& $-40 \div 65$ & & \pm 50 or $5 \%$ \\
& $($ outdoor $)$ & & \\
Accuracy & \pm 0.3 & \pm 3 & \\
\hline
\end{tabular}

Table 7

Shape-fit and magnitude-fit metrics for all the simulated rooms of the upper floor for the total of the examined period.

\begin{tabular}{cccccc}
\hline Metrics & $\begin{array}{c}\text { Main } \\
\text { bedroom }\end{array}$ & Son's room & $\begin{array}{c}\text { Daughter's } \\
\text { room }\end{array}$ & Corridor & W.C. \\
\hline $\begin{array}{c}\text { Spearman's } \\
\text { coefficient }\end{array}$ & 0.92 & 0.85 & 0.92 & 0.92 & 0.95 \\
Absolute & & & & \\
average & 0.3 & 0.6 & 0.5 & 0.3 & 0.6 \\
temperature & 0 & & & \\
difference & & & & \\
$\left({ }^{\circ} \mathrm{C}\right)$ & & & & \\
\hline
\end{tabular}




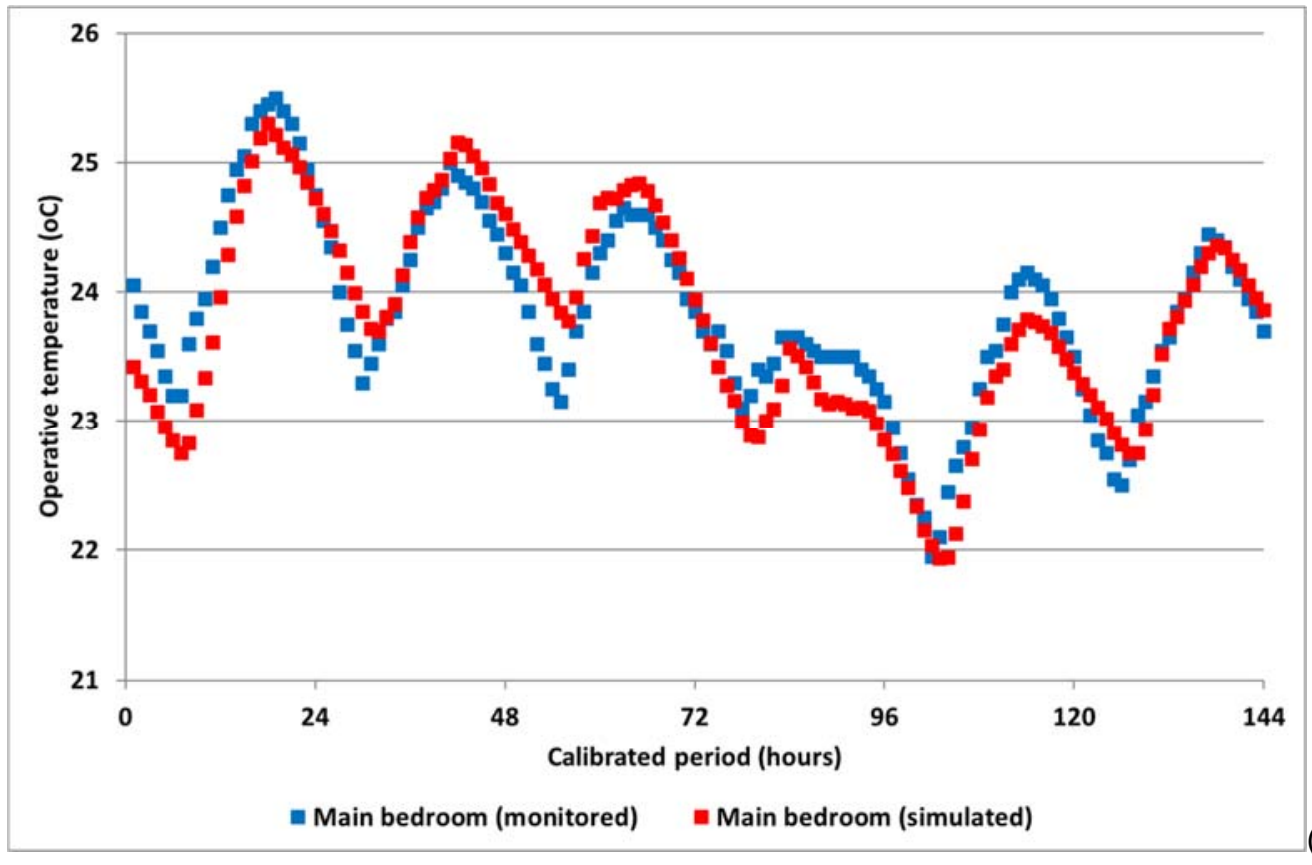

(a)

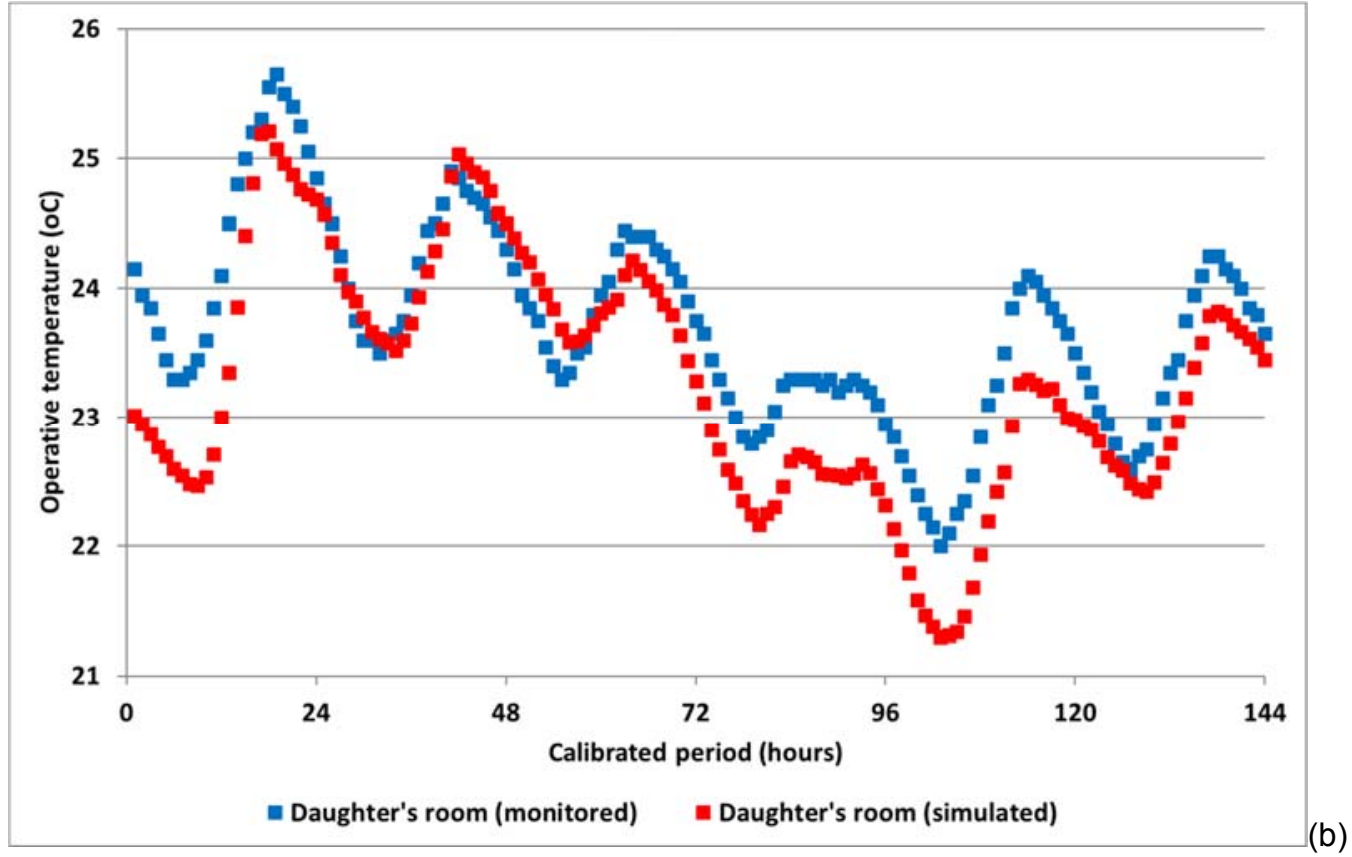




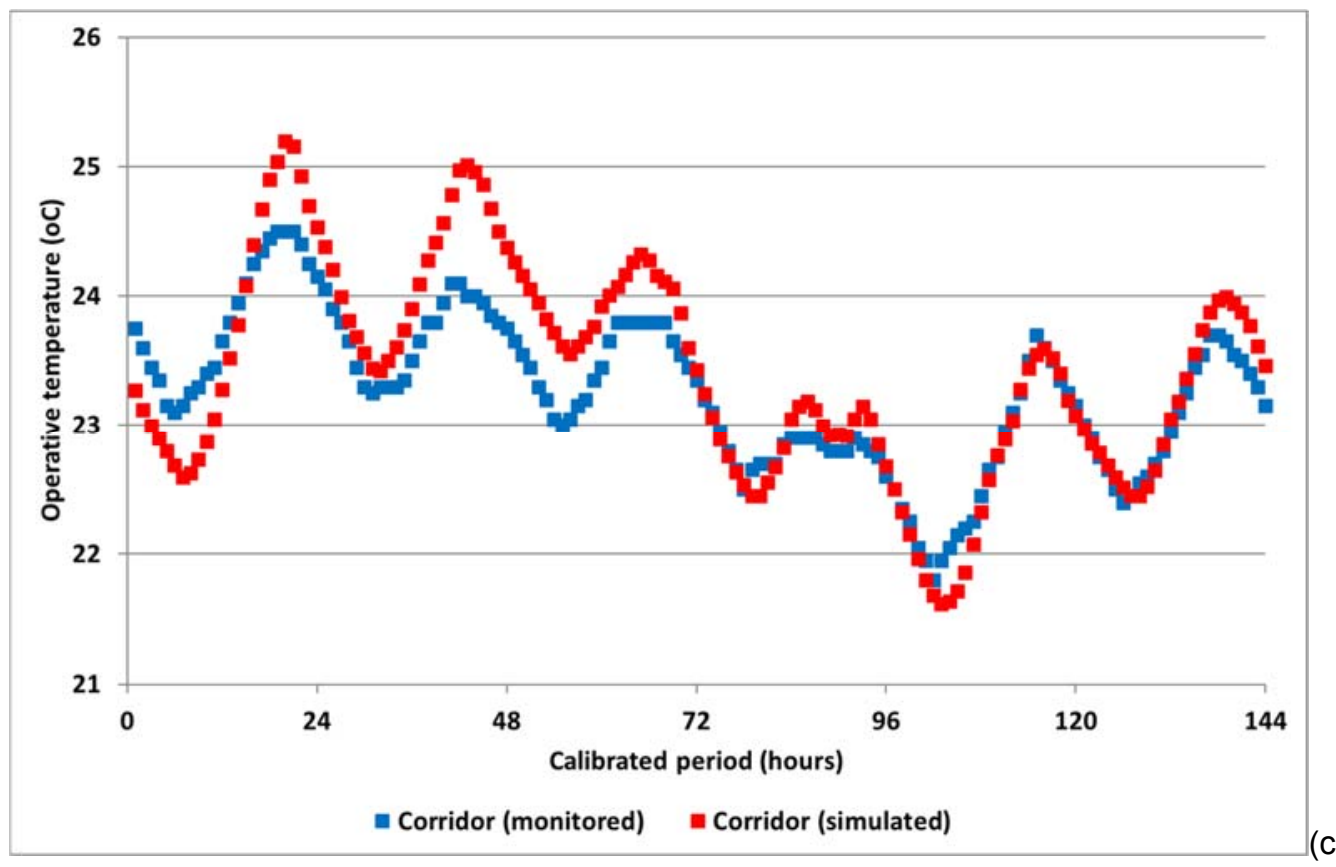

Fig. 5. Monitored and simulated indoor operative temperature $\left({ }^{\circ} \mathrm{C}\right)$ series for the examined period and for different rooms of the upper floor (a: main bedroom, b: daughter's room and c: corridor).

\subsection{Operational functions of window systems-Number of opening steps analysis}

This section presents the comparison of the indoor thermal environments of the three-simulated bedrooms and the upper floor of the case study in total, based on two different thermal comfort and overheating assessment metrics (static and dynamic), four criteria (static: $27^{\circ} \mathrm{C}, 28^{\circ} \mathrm{C}$ and dynamic: Category II, Category I in Table 5) and for two different operational functions (control approaches) of the developed window system that have a different number of steps for the window actuator until the full opening of the window. The first control approach has three opening steps (25\%/50\%/100\%; Fig. 2) and the second approach has five opening steps $(10 \% / 25 \% / 50 \% / 75 \% / 100 \%$; Fig. 2). The advantage of the 3-step approach is that the ventilative cooling strategy is more efficient, because the windows open faster (full opening in 3 time step intervals). The advantage of the 5 -step is that the natural ventilation is more controllable in relation to the intense extreme outdoor conditions (wind speed) and could therefore in many cases eliminate the summer discomfort and the risk of overheating without causing considerable draft problems, high internal air velocities (internal damages) and considerable undercooling incidents. The time interval for the algorithm in both examined cases is similar, 
30 minutes (Fig. 2). The developed algorithm is applied during all day for the whole examined period. The analysis covers different constant indoor natural ventilation cooling set points (22$26^{\circ} \mathrm{C}$ ). Previous research has shown that ventilative cooling set points for similar automated window systems range inside this temperature band and are often around $24^{\circ} \mathrm{C}$ for these climatic conditions [26]. The parametric analysis will highlight which step-approach causes less discomfort and overheating risk for different examined set points.

Figs. 6 (a-d) present the percentage difference (delta; \%) of the overheating risk and thermal discomfort for different indoor natural ventilation cooling set points, number of opening steps, metrics, criteria and rooms. The difference is positive for the majority of the set points, criteria and examined rooms of the upper floor. For all the assessed rooms and the floor in total, the differences are negligible (less than $0.5 \%$ ) for low and medium natural ventilation cooling set points $\left(22\right.$ to $\left.24^{\circ} \mathrm{C}\right)$. For $22^{\circ} \mathrm{C}$ degrees, the adaptive approach (criterion Category I) and the south-oriented rooms, the difference is more profound (close to minus 1\%). For higher set points $\left(25\right.$ and $26^{\circ} \mathrm{C}$ ), the differences are more profound (positive) for all rooms (especially criteria $27^{\circ} \mathrm{C}$ and Category I). The maximum value is resulted for the maximum set point of the parametric analysis, $26^{\circ} \mathrm{C}$, for all the criteria and rooms. High trigger set points, close to the upper limits of the assessment criteria, result in lower performance of the ventilative cooling strategy. Higher internal temperatures occur when set points are set to high values and therefore the 3-step opening approach is suggested in these cases to provide ventilative cooling as fast as possible. The 3-step approach is suggested also for hotter climatic conditions with low ventilative cooling potential.

The results indicate that the effectiveness of the ventilative cooling strategy and the performance of the window system for these climatic conditions is not affected by the number of steps (3 or 5) for low and medium indoor natural ventilation cooling set points. 


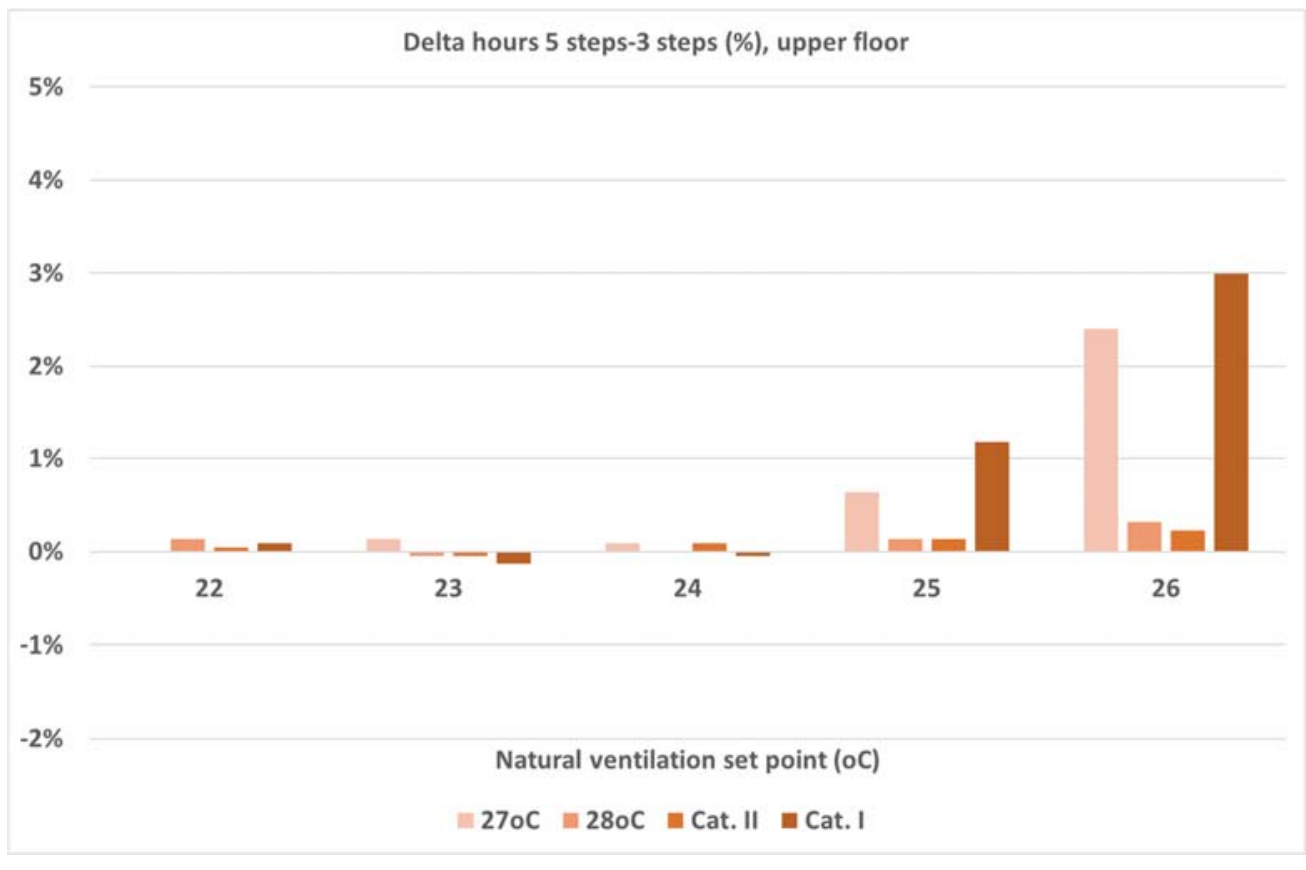

(a)

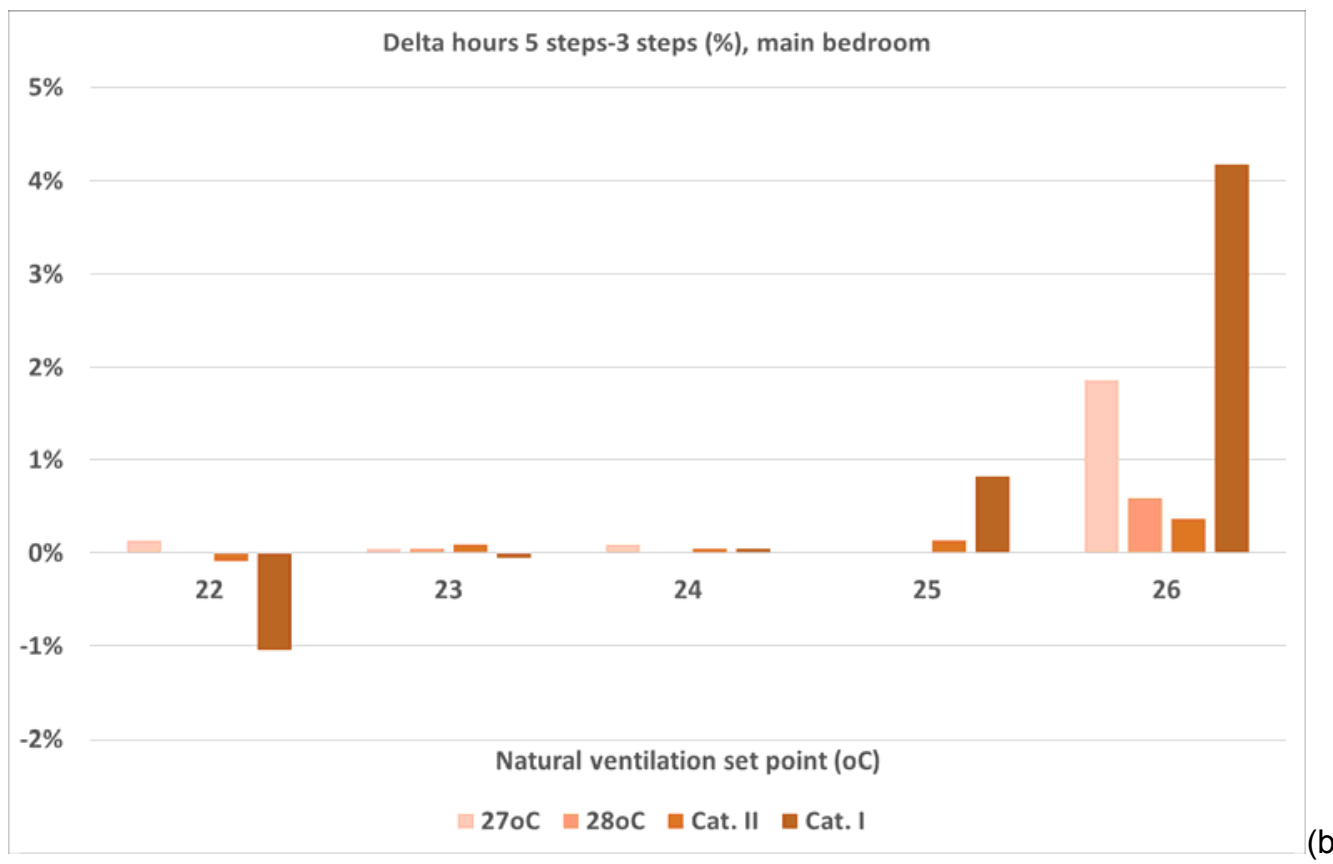



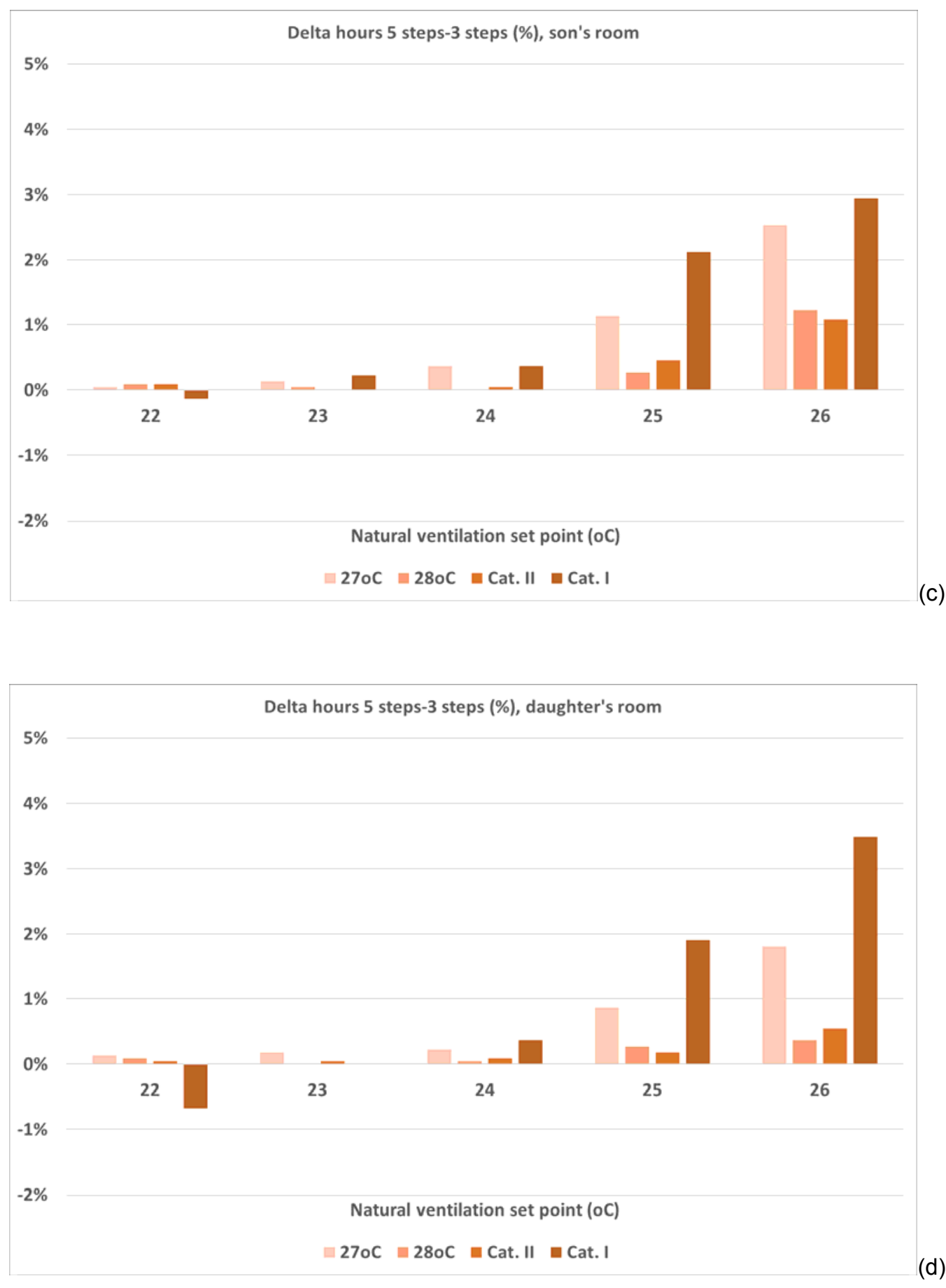

(d)

Fig. 6. Percentage difference-delta (5-step minus 3-step approach; \%) of thermal discomfort and overheating risk for different rooms (a: upper floor on average, b: main bedroom, c: son's room and d: daughter's room) during the examined summer period and for different assessment metrics-criteria and indoor natural ventilation cooling set points. 
3.3 Operational functions of window systems-Static versus dynamic indoor natural ventilation cooling set points

The determination of the optimum set point of a developed control algorithm is fundamental for the efficiency of the ventilative cooling method and the thermal optimization of the space. In this section, two different approaches have been examined for the determination of the optimum indoor natural ventilation cooling set point for actuating the window components. The first one is based on static discreet values of operative temperature and the second one on dynamically changing values based on the adaptive comfort temperature. The advantage of the former approach is that the occupant is aware about the set point values and has a physical feeling, understanding and responsibility about them. The advantage of the latter approach is that the system may calculate the dynamic set point with past outdoor temperature monitored values (Eqs. 1 and 2). This approach makes the window system more automated.

For this comparison between the two control approaches, all the rooms of the upper floor with window systems use the same approach (i.e. all static or all dynamic) and the same value (static) for the total of the examined period (summer 2016). The examined ranges of static set points are from 22 to $26^{\circ} \mathrm{C}\left(1^{\circ} \mathrm{C}\right.$ intervals). The ranges of dynamic set points are from $\pm 2^{\circ} \mathrm{C}$ to comfort temperature $\left(0.5^{\circ} \mathrm{C}\right.$ intervals). In addition, the algorithm follows the 5 -step approach as described in Section 2.1 (Fig. 2). The time interval for the algorithm is the same in both examined cases (30 minutes). The algorithm is applied during the whole day.

Table 8 presents the ranking (high frequency to low frequency of thermal discomfort and risk) of the set points for both control approaches assessed by the two discomfort and overheating metrics and four criteria that were described in Sections 2.3. At the top of the Table there are the set points with the lowest thermal discomfort or risk. For all the rooms and floor in total, the static set points $\left(22^{\circ} \mathrm{C}\right.$ and $\left.23^{\circ} \mathrm{C}\right)$ performs better than any dynamic set point for all the evaluating metrics and criteria (dynamic and static). Both northern and southern oriented rooms show similar results (Table 8 ).

It can be seen from Table 8 that the higher the set point value, the higher the thermal discomfort or risk. The static metrics have been optimized with the maximum hours of ventilative cooling. This has been accomplished by low indoor natural ventilation cooling set points $\left(22^{\circ} \mathrm{C}\right.$ for this particular research). Dynamic criteria assess both overheating and undercooling incidents. 
Categories I and II have been optimized in different set points $\left(22^{\circ} \mathrm{C}\right.$ and $\left.23^{\circ} \mathrm{C}\right)$. Different case studies in different climates and with different internal and solar loads will result in different optimum set points.

Table 8

Ranking (lowest to highest frequency) of static and dynamic indoor natural ventilative cooling set points $\left({ }^{\circ} \mathrm{C}\right)$, for three rooms (main bedroom, son's room and daughter's room) and upper floor (average), and four criteria (static: $27^{\circ} \mathrm{C}, 28^{\circ} \mathrm{C}$ and dynamic: Category II, Category I; $\mathrm{T}_{\text {cfrt. }}$ : stands for adaptive comfort temperature Eq. 1).

\begin{tabular}{|c|c|c|c|c|c|c|c|c|}
\hline \multirow{2}{*}{ Discomfort } & \multicolumn{4}{|c|}{ Upper floor } & \multicolumn{4}{|c|}{ Main bedroom } \\
\hline & $27^{\circ} \mathrm{C}$ & $28^{\circ} \mathrm{C}$ & Cat. II & Cat. I & $27^{\circ} \mathrm{C}$ & $28^{\circ} \mathrm{C}$ & Cat. II & Cat. I \\
\hline \multirow{13}{*}{$\begin{array}{l}\text { Lowest } \\
\text { frequency }\end{array}$} & 22 & 22 & 22 & 23 & 22 & 22 & 22 & 23 \\
\hline & $T_{\text {cfrt. }}-2$ & $T_{\text {cfrt. }}-2$ & $T_{\text {cfrt. }}-2$ & $T_{\text {cfrt. }}-1$ & $T_{\text {cfrt. }}-2$ & $T_{\text {cfrt. }}-2$ & 23 & $\mathrm{~T}_{\text {cfrt. }}-1.5$ \\
\hline & 23 & 23 & 23 & 24 & 23 & 23 & $T_{\text {cfrt. }}-2$ & 24 \\
\hline & $\mathrm{T}_{\text {cfrt. }}-1.5$ & $\mathrm{~T}_{\text {cfrt. }}-1.5$ & $\mathrm{~T}_{\text {cfrt. }}-1.5$ & $T_{\text {cfrt.- }}-1.5$ & $\mathrm{~T}_{\text {cfrt. }}-1.5$ & $\mathrm{~T}_{\text {cfrt. }}-1.5$ & $\mathrm{~T}_{\text {cfrt. }}-1.5$ & $T_{\text {cfrt. }}-2$ \\
\hline & 24 & $T_{\text {cfrt. }}-1$ & $T_{\text {cfrt.- }}-1$ & $T_{\text {cfrt. }}-0.5$ & $T_{\text {cfrt.-1 }}$ & $T_{\text {cfrt. }}-1$ & $T_{\text {cfrt. }}-1$ & 22 \\
\hline & $T_{\text {cfrt. }}-1$ & 24 & 24 & $T_{\text {cfrt. }}-2$ & 24 & 24 & 24 & $T_{\text {cfrt. }}-1$ \\
\hline & $\mathrm{T}_{\text {cfrt. }}-0.5$ & $T_{\text {cfrt. }}-0.5$ & $\mathrm{~T}_{\text {cfrt. }}-0.5$ & 22 & $\mathrm{~T}_{\text {cfrt. }}-0.5$ & 25 & $\mathrm{~T}_{\text {cfrt. }}-0.5$ & $\mathrm{~T}_{\text {cfrt. }}-0.5$ \\
\hline & 25 & $\mathrm{~T}_{\text {cfrt. }}$ & $T_{\text {cfrt. }}$ & $T_{\text {cfrt. }}$ & 25 & $\mathrm{~T}_{\text {cfrt. }}-0.5$ & $\mathrm{~T}_{\text {cfrt. }}$ & $\mathrm{T}_{\text {cfrt. }}$ \\
\hline & $T_{\text {cfrt. }}$ & 25 & 25 & 25 & $T_{\text {cfrt. }}$ & $\mathrm{T}_{\text {cfrt. }}$ & 25 & 25 \\
\hline & $\mathrm{T}_{\text {cfrt. }}+0.5$ & 26 & $T_{\text {cfrt. }}+0.5$ & $T_{\text {cfrt. }}+0.5$ & $\mathrm{~T}_{\text {cfrt. }}+0.5$ & $\mathrm{~T}_{\text {cfrt. }}+0.5$ & $\mathrm{~T}_{\text {cfrt. }}+0.5$ & $\mathrm{~T}_{\text {cfrt. }}+0.5$ \\
\hline & 26 & $\mathrm{~T}_{\text {cfrt. }}+0.5$ & $\mathrm{~T}_{\text {cfrt. }}+1$ & $\mathrm{~T}_{\text {cfrt. }}+1$ & 26 & 26 & 26 & $\mathrm{~T}_{\text {cfrt. }}+1$ \\
\hline & $\mathrm{T}_{\text {cfrt. }}+1$ & $T_{\text {cfrt. }}+1$ & 26 & 26 & $\mathrm{~T}_{\text {cfrt. }}+1$ & $T_{\text {cfrt. }}+1$ & $T_{\text {cfrt. }}+1$ & $\mathrm{~T}_{\text {cfrt. }}+1.5$ \\
\hline & $T_{\text {cfrt. }}+1.5$ & $T_{\text {cfrt. }}+1.5$ & $T_{\text {cfrt. }}+1.5$ & $T_{\text {cfrt. }}+1.5$ & $T_{\text {cfrt. }}+1.5$ & $T_{\text {cfrt. }}+1.5$ & $T_{\text {cfrt. }}+1.5$ & 26 \\
\hline $\begin{array}{c}\text { Highest } \\
\text { frequency }\end{array}$ & $\mathrm{T}_{\text {cfrt. }}+2$ & $T_{\text {cfrt. }}+2$ & $\mathrm{~T}_{\text {cfrt. }}+2$ & $T_{\text {cfrt. }}+2$ & $\mathrm{~T}_{\text {cfrt. }}+2$ & $\mathrm{~T}_{\text {cfrt. }}+2$ & $\mathrm{~T}_{\text {cfrt. }}+2$ & $\mathrm{~T}_{\text {cfrt. }}+2$ \\
\hline \multirow{2}{*}{ Discomfort } & \multicolumn{4}{|c|}{ Son's room } & \multicolumn{4}{|c|}{ Daughter's room } \\
\hline & $27^{\circ} \mathrm{C}$ & $28^{\circ} \mathrm{C}$ & Cat. II & Cat. I & $27^{\circ} \mathrm{C}$ & $28^{\circ} \mathrm{C}$ & Cat. II & Cat. I \\
\hline $\begin{array}{l}\text { Lowest } \\
\text { frequency }\end{array}$ & 22 & 22 & 22 & 23 & 22 & 22 & 22 & 23 \\
\hline
\end{tabular}




\begin{tabular}{|c|c|c|c|c|c|c|c|c|}
\hline & 23 & $T_{\text {cfrt. }}-2$ & $T_{\text {cfrt. }}-2$ & $T_{\text {cfrt. }}-1.5$ & $T_{\text {cfrt. }}-2$ & $T_{\text {cfrt. }}-2$ & $T_{\text {cfrt. }}-2$ & $\mathrm{~T}_{\text {cfrt. }}-1.5$ \\
\hline & $T_{\text {cfrt. }}-2$ & 23 & 23 & $T_{\text {cfrt. }}-1$ & 23 & 23 & 23 & $T_{\text {cfrt. }}-2$ \\
\hline & $\mathrm{T}_{\text {cfrt. }}-1.5$ & $T_{\text {cfrt. }}-1.5$ & $T_{\text {cfrt. }}-1.5$ & 24 & $\mathrm{~T}_{\text {cfrt. }}-1.5$ & $T_{\text {cfrt. }}-1.5$ & $\mathrm{~T}_{\text {cfrt. }}-1.5$ & $T_{\text {cfrt. }}-1$ \\
\hline & 24 & $T_{\text {cfrt. }}-1$ & 24 & $T_{\text {cfrt. }}-2$ & 24 & 24 & $T_{\text {cfrt. }}-1$ & 24 \\
\hline & $\mathrm{T}_{\text {cfrt. }}-1$ & 24 & $T_{\text {cfrt. }}-1$ & 22 & $T_{\text {cfrt. }}-1$ & $T_{\text {cfrt.- }}-1$ & 24 & 22 \\
\hline & $\mathrm{T}_{\text {cfrt. }}-0.5$ & $T_{\text {cfrt. }}-0.5$ & $\mathrm{~T}_{\text {cfrt. }}-0.5$ & $\mathrm{~T}_{\text {cfrt. }}-0.5$ & $T_{\text {cfrt. }}-0.5$ & $T_{\text {cfrt. }}-0.5$ & $\mathrm{~T}_{\text {cfrt. }}-0.5$ & $\mathrm{~T}_{\text {cfrt. }}-0.5$ \\
\hline & 25 & 25 & $\mathrm{~T}_{\text {cfrt. }}$ & $T_{\text {cfrt. }}$ & 25 & 25 & $T_{\text {cfrt. }}$ & $T_{\text {cfrt. }}$ \\
\hline & $T_{\text {cfrt. }}$ & $T_{\text {cfrt. }}$ & 25 & 25 & $T_{\text {cfrt. }}$ & $T_{\text {cfrt. }}$ & 25 & 25 \\
\hline & $\mathrm{T}_{\text {cfrt. }}+0.5$ & $\mathrm{~T}_{\text {cfrt. }}+0.5$ & $\mathrm{~T}_{\text {cfrt. }}+0.5$ & $\mathrm{~T}_{\text {cfrt. }}+0.5$ & $\mathrm{~T}_{\text {cfrt. }}+0.5$ & $\mathrm{~T}_{\text {cfrt. }}+0.5$ & $\mathrm{~T}_{\text {cfrt. }}+0.5$ & $\mathrm{~T}_{\text {cfrt. }}+0.5$ \\
\hline & $\mathrm{T}_{\text {cfrt. }}+1$ & 26 & $\mathrm{~T}_{\text {cfrt. }}+1$ & $\mathrm{~T}_{\text {cfrt. }}+1$ & $\mathrm{~T}_{\text {cfrt. }}+1$ & 26 & $\mathrm{~T}_{\text {cfrt. }}+1$ & $\mathrm{~T}_{\text {cfrt. }}+1$ \\
\hline & 26 & $T_{\text {cfrt. }}+1$ & 26 & 26 & 26 & $T_{\text {cfrt. }}+1$ & 26 & $\mathrm{~T}_{\text {cfrt. }}+1.5$ \\
\hline & $\mathrm{T}_{\text {cfrt. }}+1.5$ & $\mathrm{~T}_{\text {cfrt. }}+1.5$ & $\mathrm{~T}_{\text {cfrt. }}+1.5$ & $\mathrm{~T}_{\text {cfrt. }}+1.5$ & $\mathrm{~T}_{\text {cfrt. }}+1.5$ & $\mathrm{~T}_{\text {cfrt. }}+1.5$ & $\mathrm{~T}_{\text {cfrt. }}+1.5$ & 26 \\
\hline $\begin{array}{l}\text { Highest } \\
\text { frequency }\end{array}$ & $T_{\text {cfrt. }}+2$ & $T_{\text {cfrt. }}+2$ & $T_{\text {cfrt. }}+2$ & $T_{\text {cfrt. }}+2$ & $T_{\text {cfrt. }}+2$ & $\mathrm{~T}_{\text {cfrt. }}+2$ & $\mathrm{~T}_{\text {cfrt. }}+2$ & $\mathrm{~T}_{\text {cfrt. }}+2$ \\
\hline
\end{tabular}

\section{Conclusions}

Passive and hybrid ventilation and ventilative cooling methods, techniques, strategies and technologies may significantly decrease the environmental impact of residences and create healthy and comfortable indoor spaces. One of the challenges with assessing and demonstrating the benefits of automated controlled ventilative cooling strategies is the lack of well documented, mature and validated BPS tools which may replicate and represent precisely the complexity of air-movement physics and the control of the automated systems.

This research works presents a representation and simulation of a developed ventilative cooling algorithm on coupled BPS environments through a well-defined proposed framework and workflow. Under this framework that the use of ESP-r and BCVTV tools facilitate, the simulation of any other developed window system or ventilative cooling concept for different climatic conditions and building types is possible.

An analytical parametric analysis of the developed window system in roof window configurations of a typical single-family house in Denmark was conducted and it was found that the effectiveness and performance of the ventilative cooling strategy for these climatic conditions was not affected by the number of opening steps ( 3 or 5 ) for low and medium natural indoor ventilation cooling set points $\left(22-24^{\circ} \mathrm{C}\right)$. In addition, for all the examined rooms, the static 
set points perform better (best results with $22^{\circ} \mathrm{C}$ and $23^{\circ} \mathrm{C}$ ) than the dynamic for all the evaluating metrics and criteria (dynamic and static) that were included in this study.

Further investigation of the developed window system and algorithm in other building types and climatic conditions is suggested for future work. The description of the ventilative cooling heuristic algorithm of the window system can be used as a baseline for further development of window systems for residential cases in temperate climates or in more complicated architectural layouts and building types. The examination of different dynamic-based ventilative cooling set points resulting from future climatic conditions could also be investigated in the future. In addition, the proposed window system outputs of this research could be used as supporting material for installed window systems in these climatic conditions. However, the outputs are sensitive to climatic conditions and building types, and therefore additional modelling by following a similar methodology as in this study is recommended.

\section{Acknowledgement}

The authors are presently contributing to the ongoing work for investigating and maturing ventilative cooling as an attractive and energy-efficient solution to avoid overheating of both new and renovated buildings within the IEA EBC Annex 62: Ventilative Cooling. The research was developed within the framework of the project "Ventilative cooling in energy renovated residences" of Aalborg University, Denmark, and was supported by EUDP (Energy Technology Development and Demonstration Program) and VELUX A/S, DOVISTA A/S and VISILITY ApS (Grant number 64013-0544/2014-2017). Part of this work has been developed with ARENS, under a Commonwealth Grant Agreement with the Australian Government-Department of Industry and Science.

\section{References}

REHVA (2011). Indoor climate quality assessment. Brussels: Federation of European Heating, Ventilation and Air-conditioning Associations.

2) Adekunle TO, Nikolopoulou M (2016). Thermal comfort, summertime temperatures and overheating in prefabricated timber housing. Journal of Building and Environment, 103: 21-35. 
3) Mlakar J, Strancar J (2011). Overheating in residential passive house: solution strategies revealed and confirmed through data analysis and simulations. Journal of Energy and Buildings, 43: 1443-1451.

4) Figueiredo A, Figueira J, Vicente R, Maio R (2016). Thermal comfort and energy performance: sensitivity analysis to apply the Passive House concept to the Portuguese climate. Journal of Building and Environment, 103: 276-288.

5) Sameni SMT, Gaterell M, Montazami A, Ahmed A (2015). Overheating investigation in UK social housing flats built to the Passivhaus standard. Journal of Building and Environment, 92: 222-235.

6) Larsen TS, Jensen JL, Daniels O (2012). The Comfort Houses: Measurements and analysis of the indoor environment and energy consumption in 8 Passive Houses 2008-2011. Aalborg, Denmark: Aalborg University.

7) Janson U (2010). Passive Houses in Sweden-from design to evaluation of four demonstration projects. Lund, Sweden: Lund University.

8) Danish Transport and Construction Agency (2015). Danish regulation BR 2015. Available at http://bygningsreglementet.dk/br1500 id91/0/42. Accessed 15 Mar 2017.

9) Psomas T, Heiselberg P, Duer K, Bjørn E (2016). Control strategies for ventilative cooling of overheated houses. In: Proceedings of the 12th Clima Conference (REHVA), Aalborg, Denmark.

10) Santamouris M, Kolokotsa D (2013). Passive cooling dissipation techniques for buildings and other structures: the state of the art. Journal of Energy and Buildings, 57: 74-94. 11) Kolokotroni M, Heiselberg P (2015). Ventilative cooling. State of the art review. Aalborg, Denmark: University of Aalborg.

12) Santamouris $M$, Sfakianaki A, Pavlou $K$ (2010). On the efficiency of night ventilation techniques applied to residential buildings. Journal of Energy and Buildings, 42: 1309-1313.

13) EN 15251 (2007). Indoor environmental input parameters for design and assessment of energy performance of buildings addressing indoor air quality, thermal environment, lighting and acoustics. Belgium: European Committee for Standardization.

14) Sorgato MJ, Melo AP, Lamberts R (2016). The effect of window opening ventilation control on residential building energy consumption. Journal of Energy and Buildings, 133: 1-13. 
15) Wang L, Greenberg S (2015). Window operation and impacts on building energy consumption. Journal of Energy and Buildings, 92: 313-321.

16) Sun K, Hong T (2017). A simulation approach to estimate energy savings potential of occupant behavior measures. Journal of Energy and Buildings, 136: 43-62.

17) D'Oca S, Fabi V, Cognati S, Andersen R (2014). Effect of thermostat and window opening occupant behavior models on energy use in homes. Journal of Building Simulation, 7 : 683-694.

18) Polinder H, Schweiker M, Yan D, Olensen B, Bednar T (2013). Occupant behavior and modelling: separate document volume 2. Total energy use in buildings. Analysis and evaluation methods. Final report Annex 53 International Energy Agency. UK: Institute for Building Environment and Energy Conservation.

19) Yan D, O'Brien W, Hong T, Feng X, Gunay HB, Tahmasebi F, Mahdavi A (2015). Occupant behavior modeling for building performance simulation: Current state and future challenges. Journal of Energy and Buildings, 107: 264-278.

20) Mayer C, Antretter F (2011). User behavior regarding natural ventilation-state of the art and research needs. In: Proceedings of the 9th Nordic Symposium on Building Physics, Finland.

21) Andersen R, Fabi V, Toftum J, Cognati S, Olesen B (2013). Window opening behavior modelled from measurements in Danish dwellings. Journal of Building and Environment, 69: $101-113$.

22) Cali D, Andersen R, Müller D, Olesen B (2016). Analysis of occupant's behavior related to the use of windows in German households. Journal of Building and Environment, 103: 5469.

23) Fabi $V$, Andersen $R$, Cognati $S$, Olesen $B$ (2013). A methodology for modelling energyrelated human behaviour: Application to window opening behaviour in residential buildings. Journal of Building Simulation, 6: 415-427.

24) Torcellini P, Pless S, Deru M, Griffith B, Long N, Judkoff R (2006). Lessons learned from case studies of six high-performance buildings. National Renewable Energy Laboratory. Available at http://www.nrel.gov/docs/fy06osti/37542.pdf. Accessed 15 Mar 2017. 

renovations of single family houses: Multicriteria analysis and assessment. Journal of Energy and Buildings, 117: 138-148.

26) Psomas T, Heiselberg P, Lyme T, Duer K (2017). Automated roof window control system to address overheating on renovated houses: Summertime assessment and intercomparison. Journal of Energy and Buildings, 138: 35-46.

27) Bhatt J, Verma HK (2015). Design and development of wired building automation systems. Journal of Energy and Buildings, 103: 396-413.

28) Nguyen TA, Aiello M (2013). Energy intelligent buildings based on user activity: A survey. Journal of Energy and Buildings, 56: 244-257.

29) Butcher KJ (2009). Building control systems. Guide H. London: CIBSE.

30) Karjalainen $S$ (2013). Should it be automatic or manual-The occupant's perspective on the design of domestic control systems. Journal of Energy and Buildings, 65: 119-126.

31) Santamouris M (2016). Cooling the buildings-past, present and future. Journal of Energy and Buildings, 128: 617-638.

32) Dell' Osso GR, lannone F, Pierucci A, Rinaldi A (2015). Control strategies of the natural ventilation for passive cooling for an existing residential building in Mediterranean climate. In: Proceedings of the 36th AIVC Conference, Madrid, Spain.

33) Michel P, Mankibi M (2000). Advanced control strategy. Technical report Annex 35 International Energy Agency. Institute of Energy Conservation in Buildings and Community Systems.

34) Chenari B, Carrilho JD, Silva MGD (2016). Towards sustainable, energy-efficient and healthy ventilation strategies in buildings: a review. Journal of Renewable and Sustainable Energy, 59 1426-1447.

35) Dounis Al, Caraiscos C (2009). Advanced control systems engineering for energy and comfort management in a building environment-A review. Journal of Renewable and Sustainable Energy, 13: 1246-1261.

36) Shaikh PH, Nor NBM, Nallagownden P, Elamvazuthi I, Ibrahim T (2014). A review on optimized control systems for building energy and comfort management of smart sustainable buildings. Journal of Renewable and Sustainable Energy, 34: 409-429. 
37) Schulze T, Eicker U (2013). Controlled natural ventilation for energy efficient buildings. Journal of Energy and buildings, 56: 221-232.

38) Martin AJ, Fletcher J (1996). Night cooling control strategies. Building Services Research and Information Association.

39) Wetter M (2011). A view on future building system modeling and simulation. In: Hensen J (ed.), Building Performance Simulation for Design and Operation. UK: Routledge. pp 481505.

40) Energy Systems Research Unit. Available at: https://github.com/ESPrCommunity/Esp-rSource. Accessed 15 Mar 2017.

41) Lawrence Berkeley National Lab (2016). Building controls virtual test bed, version 1.5.0. Available at: http://simulationresearch.lbl.gov/bcvtb. Accessed 15 Mar 2017.

42) Hoes P, Loonen RCGM, Trčka M, Hensen JLM (2012). Performance prediction of advanced building controls in the design phase using ESP-r, BCVTB and Matlab. In: Proceedings of the 1st Building Simulation Optimization Conference (BSO2012), Loughborough, UK.

43) Fiorentini M, Kokogiannakis G, Jackson W, Ma Z (2016). Evaluation methodology and implementation for natural ventilation control strategies. In: Proceedings of the 12th Clima Conference (REHVA), Aalborg, Denmark.

44) Energy Systems Research Unit. Available at: www.esru.strath.ac.uk/Programs/ESPr.htm. Accessed 15 Mar 2017.

45) Strachan PA, Kokogiannakis G, Macdonald IA (2008). History and development of validation with the ESP-r simulation program. Journal of Building and Environment, 43: 601609.

46) Hand JW (2015). The ESP-r cookbook Energy Systems Research Unit, Department of Mechanical and Aerospace Engineering, University of Strathclyde. Available at: http://www.esru.strath.ac.uk/Documents/ESP-r cookbook june 2015.pdf. Accessed 15 Mar 2017.

47) Hensen JLM (1991). On the thermal interaction of building structure and heating and ventilation system. PhD Thesis, Technische Universiteit Eindhoven, Netherlands. 
48) Rijal HB, Tuohy P, Humphreys MA, Nicol JF, Samuel A, Clarke J (2007). Using results from field surveys to predict the effect of open windows on thermal comfort and energy use in buildings. Journal of Energy and Buildings, 39: 823-836.

49) Pang X, Nouidui TS, Wetter M, Fuller D, Liao A, Haves P (2016). Building energy simulation in real time through an open standard interface. Journal of Energy and Buildings, 117: $282-289$.

50) C. Ptolemaeus (2014). System design, modeling and simulation using Ptolemy II. Available from: http://ptolemy.org/books/Systems. Accessed 15 Mar 2017.

51) EN ISO 10456 (2009), Building materials and products-hygrothermal propertiestabulated design values and procedures for determining declared and design thermal valuestechnical corrigendum 1. Geneva: International Organization for Standards.

52) prEN 16798-1 (2016). Energy performance of buildings-part 1: Indoor environmental input parameters for design and assessment of energy performance of buildings addressing indoor air quality, thermal environment, lighting and acoustics. Brussels: European Committee for Standardization.

53) Freitas DCR, Grigorieva EA (2015). A comprehensive catalogue and classification of human thermal climate indices. International Journal of Biometeorology, 59: 109-120.

54) Carlucci S, Pagliano L (2012). A review of indices for the long-term evaluation of the general thermal comfort conditions in buildings. Journal of Energy and Buildings, 53: 194-205.

55) Carlucci S, Pagliano L, Sangalli A (2014). Statistical analysis of the ranking capability of long-term thermal discomfort indices and their adoption in optimization processes to support building design. Journal of Building and Environment, 75: 114-131.

56) Shady A, Carlucci S (2015). Impact of different thermal comfort models on zero energy residential buildings in hot climate. Journal of Energy and Buildings, 102: 117-128.

57) Peeters L, Dear Rd, Hensen J, D'haeseleer W (2009). Thermal comfort in residential buildings: comfort values and scales for building energy simulation. Journal of Applied Energy, 86: $772-780$.

58) ISO 7726 (1998). Ergonomics of the thermal environment. Instruments for measuring physical quantities. Geneva: International Organization for Standards. 
59) Judkoff R, Wortman D, O'Doherty B, Burch J (2008). A methodology for validating building energy analysis simulations. Technical report. National Renewable Energy Laboratory. Available at http://www.nrel.gov/docs/fy08osti/42059.pdf. Accessed 15 Mar 2017.

60) Strachan P, Svehla K, Kersken M, Ingo Heusler I (2016). Reliable building energy performance characterisation based on full scale dynamic measurements. Report of Subtask 4a: Empirical validation of common building energy simulation models based on in situ dynamic data. Annex 58 International Energy Agency. Belgium: Institute for Building Environment and Energy Conservation.

61) Netatmo weather station. Sensor specifications. Available at https://shop.netatmo.com/eur en/netatmo-weatherstation-en.html. Accessed 15 Mar 2017. 